CIHM

Microfiche Series (Monographs)
ICMH

Collection de microfiches (monographies)

Cenadian Institute for Historical Microreproductions / Institut canadien de microreproductions historiques
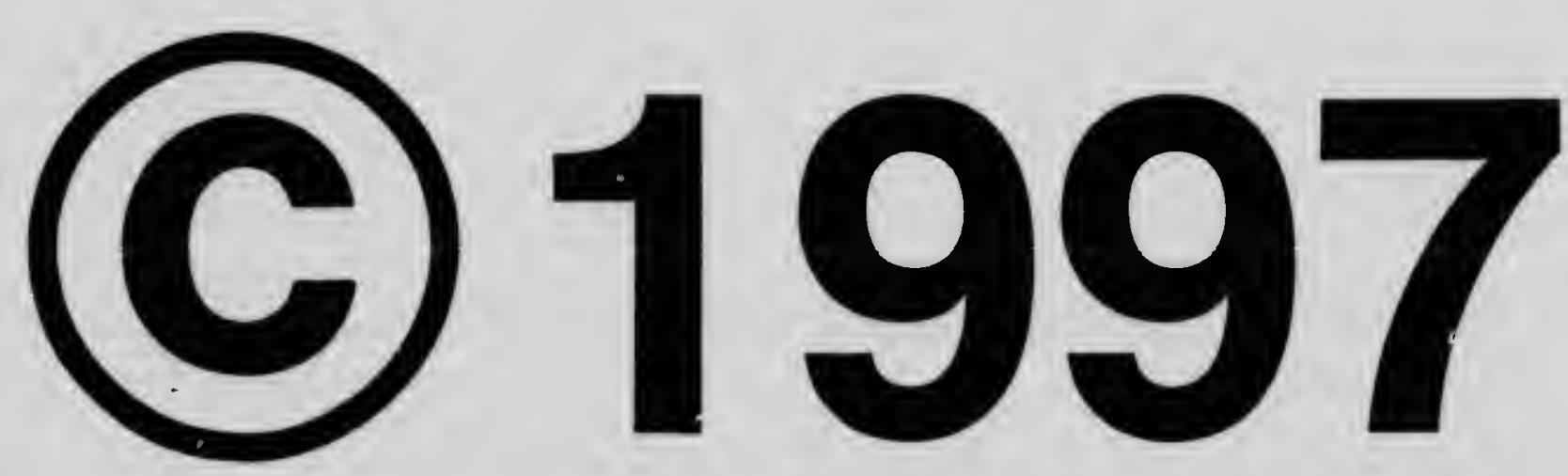


\section{Technical and Bibliographic Notes / Notes techniques et bibliographiques}

The institute has attempted to obtain the best originai copy avaliable for filming. Features of this copy which may be bibilographicaily unique, which may alter any of the images in the reproduction, or which may significantiy change the usual method of filming are checked below.

\section{Coloured covers 1}

Couverture de couleur

Covers damaged /

Couverture endommagée

Covers restored and/or iaminated /

Couverture restaurée etou pelliculée

Cover titie missing / Le tlire de couverture manque

Coloured maps / Cartes géographiques en couleur

Coioured Ink (i.e. other than blue or black) I

Encre de couleur (i.e. autre que bleue ou noire)

Coloured plates and/or illustrations I

Planches etvou illustrations en couleur

Bound with other material /

Relié avec d'autres documents

Only edition available /

Seule édition disponible

Tight binding may cause shadows or distortion along interior margin / La reliure serrée peut causer de l'ombre ou de la distorsion le long de la marge intérieure.

Blank leaves added during restorations may appear within the text. Whenever possible, these have been omitted from filming / II se peut que certaines pages blanches ajoutées lors d'une restauration apparaissent dans le texte, mais, lorsque cela était possible, ces pages n'ont pas été filmées.

Additional comments /

Commentaires supplémentaires:
L'Institut a microflime le mellieur exempialre qu'll lul a été possible de se procurer. Les détalis de cet exemplaire qui sont peut-etre uniques du point de vue bibilographique, qui peuvent modifier une image reprodulte, ou qui peuvent exiger une modification dans la méthode normale de filmage sont indiqués ci-dessous.

\section{Coioured pages / Pages de couleur}

Pages damaged / P byes endommagées

Pages restored and/or laminated /

Pages restaurées etlou pelliculées

Pages discoloured, stained or foxed $/$

Pages décolorées, tachetées ou piquées

Pages detached / Pages détachées

Showthrough / Transparence

Quality of print varies I

Qualité Inégaie de l'impression

Includes supplementary material /

Comprend du matériel supplémentaire

Pages wholly or partially obscured by errata slips, tissues, etc., have been refilmed to ensure the best possible image / Les pages totalement ou partiellement obscurcies par un feuillet d'errata, une pelure, etc., ont été filmées à nouveau de façon à obtenir la meilleure image possible.

Opposing pages with varying colouration or discolourations are filmed twice to ensure the best possible image / Les pages s'opposant ayant des colorations variables ou des décolorations sont filmées deux fois afin d'obtenir la meilleure image possible.

This hem ia filmed at the reduction ratio checked below I Ce document est mims au taux do riduction indiqus ch-deseous.

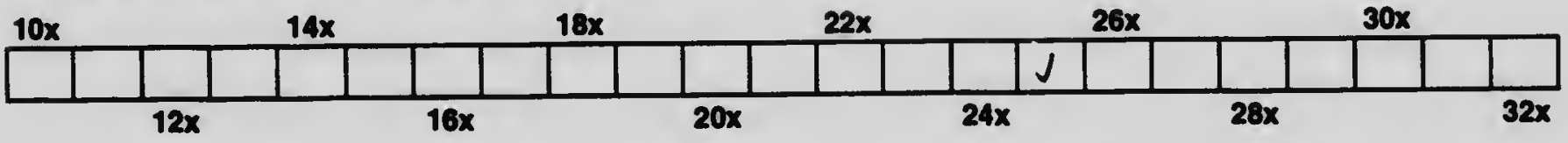


The copy fllmed here hes been reproduced thanks to the generosity of:

$$
\begin{aligned}
& \text { Lborary } \\
& \text { Acrleuture Cancola }
\end{aligned}
$$

The Images appoaring hore are the beat quallty posalble conaldering the condition and loglbillty of the original copy and In keoplng with the fliming contract specifleations.

Original coples in printed peper covers are filmed beginning with the front cover and ending on the last page with a printed or Illustrated Impresslon, or the back cover when approprlate. All other orlginal coples are fllmed beginning on the flrst page with a printed or Illustrated Impres. slon, and ending on the last page with a printed or Illustrated Impresslon.

The last recorded frame on each mlcroflche shall contaln the symbol $\longrightarrow$ imeaning "CON. TINUED"), or the symbol $\nabla$ (meaning "END"), whichever applles.

Maps, plates, cherts, etc.. may be fllmed at different reduction ratlos. Those too large to be entirely Included In one exposure are fllmed beginning In the upper loft hand corner, loft to right and top to bottom, as meny frames as required. The following dlagrams Illustrate the mothod:
L'exemplaire filmb fut reprodult orlee a la gindrosito de:

\section{Bibllothdque \\ Agriculture Conoda}

Les Images sulvantes ont us' reprodultes avec le plus grend soln, compte tonu de la condition ot de la nottots de l'oxemplalre fllmo, ot on conformlte avec les conditions du contrat de fllmage.

Les exemplalres orlginaux dont la couverture on pepler ese Imprimbe sont fllmbe on commencant par le premior plat ot en terminant solt par la dernldre page qul comporte une emprelnte d'Impression ou d'illustration, solt par lo second plat, solon lo cas. Tous les autres exemplalres orlolnaux sont fllmbe on commencant par la premlòre page qul comporte une emprolnte d'Impresslon ou d'Illustration et on torminant par la dernlore page qul comporte une telle emprolnte.

Un des symboles sulvants apparaftra sur la dernlore image de chaque microflche, selon le cas: lo aymbole $\longrightarrow$ alonifle "A SUIVRE", le symbole $\nabla$ algnifle "FIN".

Les cartes, planches, tableeux, etc., peuvent dtre fllmbs des taux do róduction dlffórents. Lorsque lo document est trop grand pour ctre reprodult en un seul cllchó. II est fllme partir de l'engle supórleur gauche, de gauche drolte. ot de haut on bas, on prenant lo nombre d'Images nócessalre. Les dlagrammes sulvants Illustront la móthode.
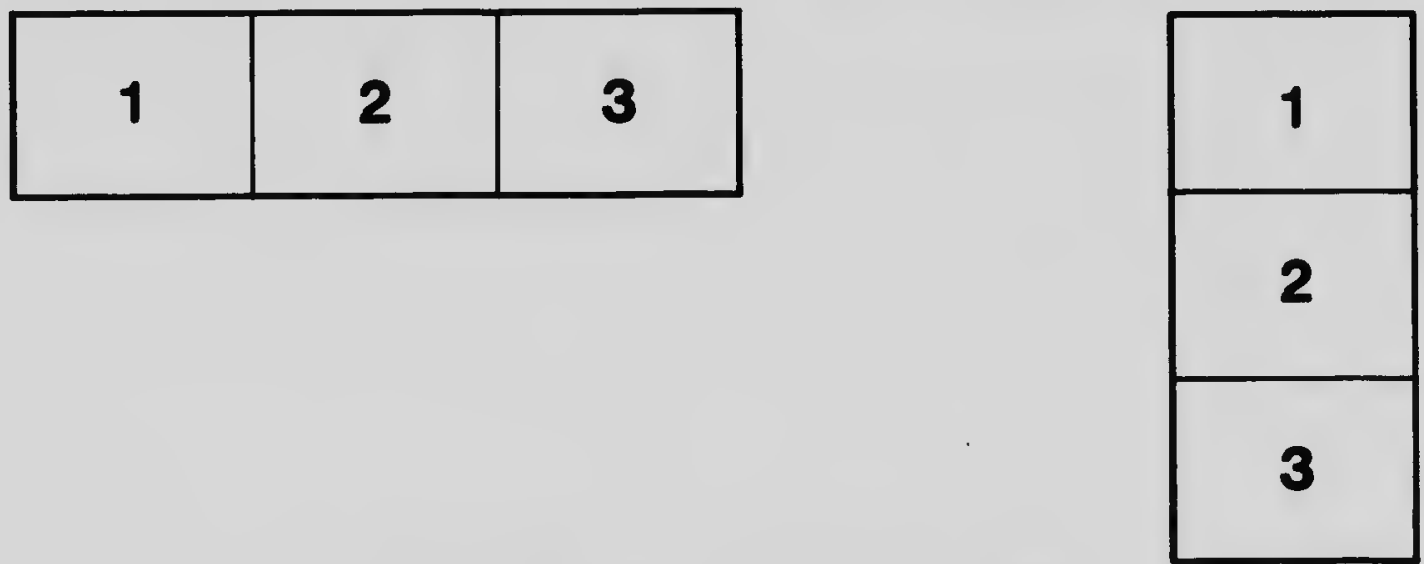

\begin{tabular}{|l|l|l|}
\hline 1 & 2 & 3 \\
\hline 4 & 5 & 6 \\
\hline
\end{tabular}




\section{macocory nsoution test CHARt}

(ANSI and ISO TEST CHART No. 2)
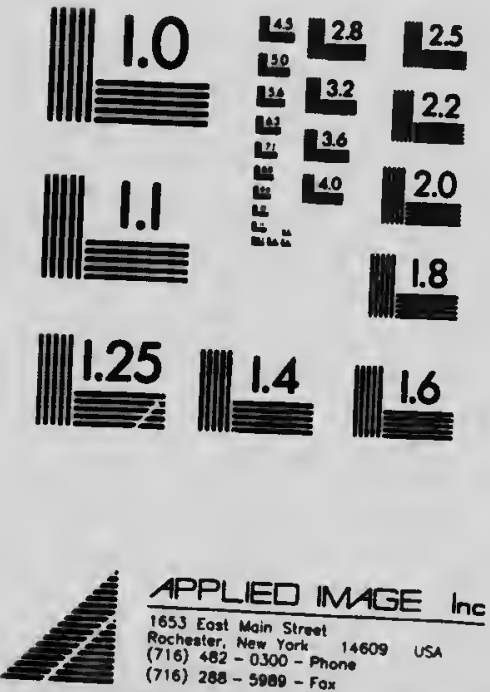


\section{th}

DEPABTIENT OF BABIOQLTURE

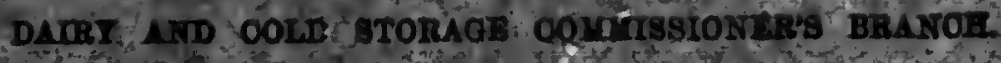

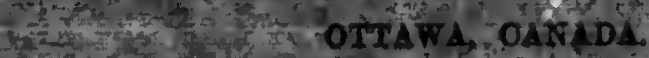

$$
\text { OANCDA. Elte }
$$

\section{CO-OPERATION AND FRUIT GROWING}

A. McNEIIL,

Ohiof Prith Divion

BUELEIIN NO 38 DAIRY AND COID STORAGE COMMISSIONER'S SERIES

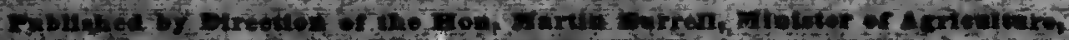
otintionit.

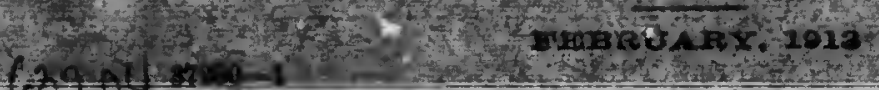


DAIRT AND COLD STORAGF: COMMISSIONEI'S BRANCII. DTTAWA, CANADA.

\title{
CO-OPERATION AND FRUIT GROWING
}

LY

\author{
A. McNEILL,
}

Chief, Fruit Division.

\section{BULLETIN NO. 38-DAIRY AND COLD STORAGE COMMISSIONER'S SERIES}

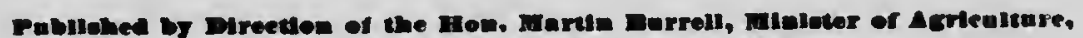
vers vara, Ont. 

To the Howourible

Otrawa, Fehruary 21, 1013.

The Mininter of Agriculturo.

Sill.-I beg to subunit for your approval the mannseript for a new bulletin on ' Co-operation and Fruit (irowing, by A. MeNeill, Chiot of the Fruit Division in this Brauch. Bulletiu 18, '('o-operation in the Marketing of Apples.' published in 1M07, is now out of print. The proposed bulletin is to some extent a revision of Bullotin 18. but it also contains much new matter relating to the subject.

I have the honour to recommend that it be publishel for distributiou an Bulletin 38 of the Daipy and Cold Storage Series.

I lave the hounon to be, sir,

Your obedient servant,

J. A. RITDDICK, Dairy and Cold Slorage Commiesioner. 


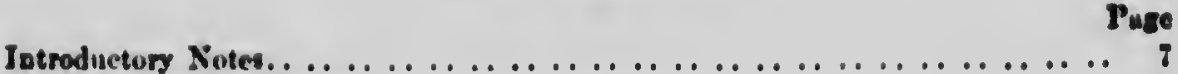

Apple Growing in C'analu.. . . . . . . . . . . . . . . . ..... 7

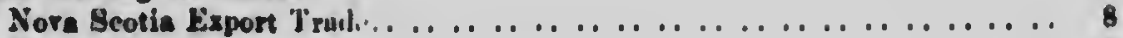

Hocent Developments..........................

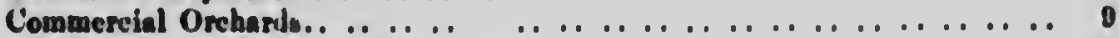

A Ploa for the Small Oreburl. . . . . . . . . . . . . . . . . . .. D

The Development of Coroperation...................... D

Competition renus Co.opnerwtion. ...................... 10

Fraud..............................

Wante.............................. 11

The Hemeds.. ......................... 11

Function of Co-operation. . . . . . . . . . . . . . . . . . 11

Fthical Principle Inrolverl. . . . . . . . . . . . . . . . . . . . . 11

Confidenes in Ieadern.. ......................

Loyalts..................................

Unedbhness.. ............................... 12

Lendenhip... ................................ 12

Co-operation in Practice... . . . . . . . . . . . . . . . . . . 13

Manarement and Coutrol.. ........................ 13

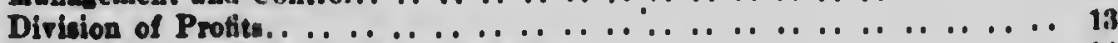

The Prewent Syotem of Packing and Sellinz. . . . . . . . . . . . . 14

Belling through Conumission Arents.. . . . . . . . . . . . . . . . . .. 15

Bhortcominge of Indiridual Growers. . . . . . . . . . . . . . . . 16

Co-operation and the Fruit Yerchant.. .................

Co-operative Amecintions and New Markets.. .. . . . . . . . . . . 16

Yartet Requirementa. . . . . . . . . . . . . . . . . . . . . . . 17

Co-operation in Production and Marketing. . . . . . . . . . . . . . 17

Iarce Quantitic........................... 18

Unilormits in Packing and Grading. . . . . . . . . . . . . Is

The Reputation of a Brand. . . . . . . . . . . . . . . . . .. 14

Co-operative Yethods and Branls. . . . . . . . . . . . . . 1 1!

Economy in Harreating and Ma.ikering.. . . . . . . . . . . . 1!

Picking Fruit when Mature. . . . . . . . . . . . . . . . 18

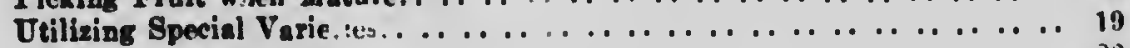

The Colvert. ... . . . . . . . . . . . . . . . . . . . 20

The Gravenstein. . . . . . . . . . . . . . . . . . . . . 20

By-products. . . . . . . . . . . . . . . . . . . . . . 20

Improventent in the Grade of (ircall Fruit................ 20

Lasociation and By-proluct Factorips.................... 20

Storage Facilities. . . . . . . . . . . . . . . . . . . . . . . . . . . 21

Warehouses in Nova Scotia.. . . . . . . . . . . . . . . . . 21

Improved Methods of Selling. . . . . . . . . . . . . . . . . 21

Packages................................. 21

Purchasing and Using Implements in Conmon... . . . . . . . . 22

Securing Expert Busines Men.. .. .. . . . . . . . . . . . . . . . . 22

Educational Value. . . . . . . . . . . . . . . . . . . . . . . . . . 22

Cash Adrances.. . . . . . . . . . . . . . . . . . . . . . . . 2 23

Distributive Co-cperation.. ....................... . . . . . .

The St. Catharines Cold Storuge and Forwarling rompany.. .. . . . 23 
The Labour Problem.. . . . . . . . . . . . . . . . . . . .. 84

Benefits to others than Members....................... 24

The Rise in the Value of Land....................... 25

Sugrestions with Reference to Organization................. 25

Forming an Association. ....................... 25

Guarantee Bonds......................... 25

Auditing.............................. 25

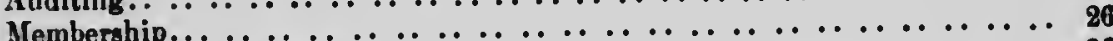

Equality of Interests....................... 26

Outside Dealing. . . . . . . . . . . . . . . . . . . . 20

Association Asscts............................. 26

Co-operative Bookkecping. ...................... 26

Incorporation. ............................. 87

Central Packing House.. . . . . . . . . . . . . . . . . . . . . . 27

Central Associationin.

The United Fruit Companies of Nova Scotia............... 28

Organization Among Existing Ontario Associatious............... 29

Co-opcrative Legislation. . . . . . . . . . . . . . . . . . . . .. 30

Propaganda. . . . ........................... 30

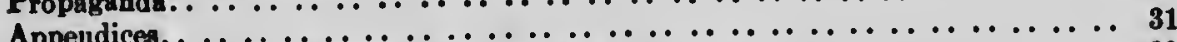

Appendix 1 Constitution and By-laws............... 32

Norfolk Fruit Growers' Association............. 32

Forest Fruit Growers and Forwarding Association..... 34

Kelowna Farmers' Fxchange (Limited)... ........ 35

Island and Gypsum Fruit Company, Ohio......... 37

Form Recommended for Ontario............. 40

Appendix 8-List of Co-operative Fruit Associations in Canada. . . . . . 42

Appendix 8-Statistics........................ 45

Apple exports from Canada by jears............ 45

" " " periods... ......... 45

Imports of apples, bananas and oranges into United Kingdom.......................... 46 


\section{CO-OPERATION AND FRUIT GROWING.}

By A. McNeill.

\section{INTRODUCTORY NOTES.}

Co-operation, in all lines of agricutural produetion and distribution, has developed rapidly during the last few years in nearly all the countries of Europe. Tho development is less marked in Ameriea, but even in America eertain lines of cocperation have reached enormous proportions, such, for instance. as the co-operative selling associations for citrous fruits in California. Agrieultural produetive cnoperation, too, has inade great progress in the States of Wiseonsin and Minnesnta III other parts of the United States co-pperative selling assuciations have becoute fuirly eommon and have worked out prineiples that can be adopted now with ennfidence.

In recent yoars there have been some remarkable developulents of co-operative effort among Canadian farmers. The Nortlıwest Grain Growers' Association bide $f_{\text {inir to }}$ revolutionize the selling of wheat in the northwest. Distributive so-operative gtures are being established throughout the Dominion, and so numerous have they become lately that it has been found desirable and possible to orranize a Dominion Union of Co-operative Assoeiations that will exercise a great influence on the distributive side of the morement.

Not less important has been the development of apple selling associations within the last few years, and it is with these that this bulletin is partieularly concerned. But it is necessary to emphasize that the general prineiples are the same and it would be impossible, even if it were deemed expedient, to attempt to disassociate the co-operative apple selling movement in Canada from the co-operative movement it: all agricultural lines in many countries. The history of co-operative apple selling associations in our own eountry is snffieiently interesting to demand special attention and it appears to be the line along whieh co-operative effort can be most easily intro. duced in many important eections of the country.

To outline in more or less detail the prineiples of eo-operation, the more desirable methods to adopt in putting these principles into praetice, and the objects to the gained by their adoption, is the purpose of this bulletin. If its perusal tends to elleourage more economical methods of production and distribution, and a more equitable division of the proceeds froin sales, the object of the bulletill will have been attained.

\section{APPLE GROWING IN CANADA.}

The apple industry of Canada originated in the orchards of the earliest settlers, planted primarily for their own use. These orchards, planted for this purpose on a somewhat generous scale, supplied not only the needs of the family, but also those of the nearby markets. So prolifie were they that even when local demands were met there was still a surplus. This formed the nueleus of the long distance and export trade. Merchants and the more enterprising growers began to ship a few barrels to the markets of Great Britain and found that the fruit was acceptable and the profits large. This ereated somewhat of a boom in orchard planting and developed the long distance and export trade to its present proportions. 
The handling of the erop naturally fell into the hands of dealers who rery quickly monopolized the trade cunnections, to such an extent that they could practically dictate the remuneration retumed to the growers, and in this condition the trade has continued almost to the present time.

Of course, the form in which this monopoly existed was in a measure dictated by slightly different conditions. The net results, however, were the same. The grower was in the hands of the middleman and was powerless to secure a fair proportion of the prices which his fruit brought in the ultimate market. In Nora Scotia the dealers were usually associated with some strong English firm who made adrances on the apples in their possession and who eventually built warehouses at the paints of production in order to secure a better hold upon the fruit. Not content with this, certain dealers often secured control of the transportation facilities, so that rival shippers and independent growers had great diffeulty in moving their fruit. Bome of the shrewdeat men among these growers, too, were employed to act as noliciting agents, and by these devices the dealers secured almost absolute control of the trade.

In Ontario, apple orchards were not 80 concentrated, and it was somethat more difficult to secure such control. Howerer, the distance from the markets and the inebility of the Englinh firms to become acquainted with the local conditions, enabled a comparatively fer men to pose as exporters. There grew up a large army of local buyers more or lew under the control of the erporters, and at times the competition among these kept prices fairly well up to a point corresponding with the price in the foreign market. In later years the competition between different buyers became merely nominal and the business in Ontario was so shrewdly organized that the apple grower got just a little more for his fruit than his actual expenses. For this reason there was no incentive to increase the orchard area. In fact after this rerime had more or les complete control, the orchard area began to fall of most gerioull, and it wa no uncommon thing in the decade beginning 1890 to see splendid orchards chopped down for firewood. It was under these circumatances that the co-operative movement began. It was adopted by Ontario as a sort of last resort. In this it follows the history of co-operation in every land and in connection with every industry. It is seldom indeed that it has been adopted during good times or while industries were flourishing. But though adopted with little hope it has never failed to improve conditions.

Tova Scotia Export Trade.-The development of the apple trade in Nova Scotia is similar to that in Ontario and it began about the same time. About 1870 shipmejits from Nova Scotia to London were in large enough cargoes to attract attention. Many of these apples were sent in sailiug vessels from local ports and, as might be expected, the condition on arrival was variuble. There was no provision for ventilation, and evell if there had beell none of those delays so common to sailing vessels, it would have been a difficult matter to have lauded apples in London to do justice to Nova Scotia. Steamers suiling from Boston werc then induced to come to Halifax for a part cargo of apples, and this helped the situation considerably. Later, of courst, Halifax secured a direct line of steamers that has served the needs of the trade more or less satisfactorily up to the present time. The exports in 1880 were only 24,000 berrels, and in $1886,177,500$ barrels. The phenomenal crop of 1896 guve a surplus of something like 500,000 barrels and the 1011 crop gave an output for export and long distance shipments of $1,500,000$ barrels, representing a total yield of about $2,000,000$ barrels. Briefly this is the history of the apple industry, both in Ontario and Nova Beotia, the only provinces that have yielded a large surplus for export.

Recent Developments.-The phenomenal inerease in the erop of Nova Scotia has been the result partly of inereased plantings, but partly also of the better care which is taken of the orchards. 
The increase in the acreage of new orchards in Ontario in the last ten yean bas probably been as great as in Nova Seotia, but these new orchards are not concentrated to the same extent. Neverthcless, they are by no menns as widely distributed as the older orchards. As a nutter of fact the decrease in the number of trees in the older mmaller orchards in this prorince has been quite equal to the increase in the number of new trees planted in larger areas and, perhaps, in more favourable situations. Modern orchard culture is also the rule in these new Ontario orchards. The outcome in both Nova Scotia and Ontario is a very large increase in the exportable surplus.

British Columbia has been planting rery rapidly of late years but the 1012 crop was the first that eeriously affected the market outside the province.

Commercial Orchards. - Recently there has been a marked change with reference to apple growing, brought about for the most part by co-operation. The older home orchards are ceasing to be profitable. It is doubtful, indeed, whether orcharding can be recommended at all, unless it be for home use or for the local market, except where co-operative methods, are used. Under the stimulus of such methods, growers are turning their attention to orcharding as a main source of income, where formerly it was only a side-line. The effect is to group the orchards in particular districts and to increase their size. It means, too, the application of business methods to this branch of horticulture. In modern phrase, orchanding is becoming ' commercialized' in Canada. The change is now taking place and we see the extraordinury spectacle of men in one part of a county receiving 82 per barrel for applee, while in the next township apples are being allowed to rot under the trees. The old order is passing away and the new is not yet thoroughly established.

A Plea for the Small Orchard.-At the present time the small grower, in neighbourhoods where orcharding is not a special feature, would appear to have received a setback. $\Lambda$ little more experience will show these small growers that it is quite possible, even in districts where apples are not a specialty, to organize co-operative selling associations so as to dispose of the fruit without difficulty and ai a fair profit. It must be admittel that of late jears the small orchard, as an adjunct to the farm, has not been remumerative. All attempts at growing four, five or half a dozen trees, which woull be sufficient to supply the needs of the home, have failed; the trees are not numerous enough to receive proper care in the busy life of the ordinary nised farm, and very quickly succumb to gen.. 'l neglect. Apparently the smallest area that can be recommended in general prac..ce is five acres, and there is no reason why, with co-operative methods, there should not be a five-acre orclard on every farm in the apple districts of Canada. This would not interfere seriously with the larger interests of the farm, and yet would be sufficient to make it worth while to securc proper implements, spray at the right time and pay some attention to marketing. With the passing of these small orchards would go many of the pleasant recollections of farm life. The old orchard is the memory that lingers longest aud liinks us most closely with the land. It would be worth while, merely as a partial solution of the depopulation problem. to institute a propagand: for a five-. cre orehard on every farm.

\section{THE DEVELOPMENT OF CO-OPERATION.}

So far as Canadian fruit growers are coneerned, they benefitted comparntively little by. the experience of co-operators in other lands, and co-aperation with them is decidedly a native growth influenced little or not at all by the theories nul practices of older countries. The result has been that our" growers have looked upon cooperation largely from the material side and have counted its henefits in proportion to the direct increase in returus for fruit. Naturally, too, the by-laws and regulations under which the first associations operated did not corresponil to any set prineiples similar to those evolved by the co-operative socicties in other lands.

$3 \div 230-2$ 
The fact that the independent Canadian evolution of co-operation does not differ materially in methods from co-operation as preticed in the older lands, should inopire confidence in Canadians to accept more readily the teachings of pioneers in this system of conducting trade. Fveryone who aspires to be useful in a co-operative way should acquaint himself with the history of co-operation in the older lands. Particularly valuable is the history of co-operation in Germeny and Denmark, but senrcely less so are the recent developments in agrieultural co-operation in Ireland under the leadership of Sir Horace Plunkett. For genernl prineiples nothing can be better than the history of distributive co-operation in (irent Britain.

I emphasizo the importance of reading co-operative history for the reason that not all the Canadian apple selling associations have been successful. $\mathbf{A}$ eareful study of the eauses of their failure will show that in every case there has been a violation of some of the principles that are now regarded by those who have studicd the subject. its fundamental to eo-operation.

Perlaps the greatest mistake which Caundian fruit growers lave made in reference to co-operation is to reyard it as an isolated movement for the purpose of securing them a few dollars more than they would otherwise obtain. In its broader outlook co-operation is a friendly ociety or a benefit association. European co-operators have recognized this and have taken for their motto, 'Each for all, and all for each.' Taking this view, co-operation implies not only getting something that you did not have beforc, but also giving something or helping some one whom you could not otherwise help, and the giving or helping end is quite as important as the receiving end.

\section{COMPETITION VERSUS CO-OPERATION.}

Few Canadian eo-operators recognize that eo-operation is an entirely new method of doing business. It is not merely a modification of an older method but something founded upon a different if not antagonistie principle. The prevailing system of marketing is founded upon competition, the praetical motto of whieh is, "Every man for himself.' The natural result of this is that a few individuals receive most of the prizes. C. R. Fay in Co-operation at Home and Abroad' defines a co-operative nociety as 'an association for the purpose of joint trading originating among the weak and conducted always in an unselfish spirit, on such terms that all who are prepared to assume the duties of membernhip may share in its rewards in propor. tion to the degree in which they make use of their association.'

It will be necessary, in the course of what follows, to point out some of the evils of the ordinary competitive system in connection with the apple industry, and in doing so it must be definitely understood that individual giowers and buyers cannot be hold altogether responsible for the disabilities under which the apple industry undoubtedly labours. It is the system under which they are working that is most at fault. It offers at every turn incentives to untruthfulncss and misrepresentation. It places in the hands of unserupulous growers and unscrupulous buyers an effective instrument of fraud and renders it more difficult for linnest inen to eonduct a legitimate business. Indied this froud in the apple busines becane so sorious in Canada that it uccessitated the passing of the Fruit Marks Act, now merged in the Inspection and Sale Aet, which has done much to correct some of the grosser evils.

Waste.-Even if there were no misrepresentation between the buyer and the grower, yet from the conditions under which the buyer works he is obliged to pick and pack the fruit and bring it to market at a much greater expense than that inlourred by co-operative methods. Under the present wasteful eompetitive system it is not too much to say that from 50 to 75 cents is added, on the average, to the cost 
of every barrel of apples before it loaves the shipping station. Tho dealere are not particularly anxious to change this if they could, so long as these additional charges are uniform in the whole trade, since pach is in good a position as his competitor, and all may shift the hurden upon either the producer or the consumer.

The want of economy does not stop at the shipping station. If the grower attempts to ship to the ultimate market on his own account, the competitive system of marketing accumulates upon the fruit a number of charges, some of them perfectly legitimate, others quite unuecessary, or, if necessary, exorbitant. But whether these cliarges are right or wrong, the individual shipper is helpless. He lias no way of illvestigating their eorrectuess.

The Remedy.-Co-operative methods suhstitute for this a more economical method of picking. packing and marketing. They also take away most of the incentives to fraudulent packing and marking. The economies that can be effected will be noted more particularly in what follows. Here it is sufficint to diret attention to the fact that this economy does not consist in supplanting oule person by another to whom a lower fee or less wages is paid. It is a method whereby oue man without undue exertion can do the work that is now being lone by two or three. So, too, cooperative methods do not propose to make men honest by law or rule. They simply take avay the present inceutives to dishonesty.

\section{FUNCTIONS OF CO-OPERATION.}

The aims of co-operation, as applied to the fruit industry, are:-

(a) To bring fruit products as directly as passible from the producer to the (onsumer.

(b) To encourage the bent inethods of production.

(e) To encourage thrift in the fruit grower, aud economy, intcllipence, enterprise and honesty in the packing, grading and marketing of fruit.

(d) To make it possible for number of small growers to establish a commereial standing that will be a guarante for grade marks or contracts.

(e) To act as a credit organization to inake advances on products in the procrss of being sold.

\section{ETHICAL PRINCIPLES INVOLVED.}

"There is an intungible something that is demanded hy co-operation as equential," "s and this is evidenced by feelings of fellowship. mutual devotion and faith ful nese? "Co-operation does not exist enduriagly without these. G. K. Holmes, United". "States Department of Agriculture, Report No. 98."

Confidence in Ieaders. - Co-operation is founderl upon mutual coufidence, loyalty to principle and unselfishness in action. In an assuciation the inembe cust have confidence in their leaders and in thei: fellow workers. Without this no progress can be made; no other virtues will compensute for its absence. uch confidence is not the blind faith that follows without reuson, nor yet is it the cold and calculating sureness that comes from perfect knowledge. The confidence which one las in leaders and in his fellow workers in this democratic age, docs not dispense with all the mechanism of personal oversight and close auditing. But it does consist in unreservedly plecing our interests in the cary of others who are working with us and whom we have no good reason to suspect of fraudulent and wifish intent. The milennium is not yet come, but it is safe to say that nine-tenths of the suspicions of the average man are without good foundation. The crininal rode in certain countries is founded upon the principle that an accuset man is guilty until he $37230-21$ 
proves bimeelf innocent. The British court of justice consider a man innecent until he is proved guilty. Applytug this principle to the working of co-operative anociations, we should consider our fellow members as worthy of our confidence until it is proved otherwise by unimpeachable ovidence.

Ioyalty. - A co-operative society cannot be fully successful simply because a few of the local srowers are keenly interested. It is essential that car member of a "o-operative association should bear in mind that the success or $f_{\text {u. }}$ lure of the organization depends upon the combined efforts of its menbers. in kiving every possible support to the morement. The ultimate success of co-operation depends largely upon the cheerful optimism and enthusiastic lnyalty of the association members. It is assumed that the leaders of the movement in any section are men of greater executive ability and better training than the average grower. Such men are capable of doing many things well. But at the same time every member must lave his minl permented with the thought that unless he gives every possible assistance the silorts of the leaders are necessarily limited.

Given good feeling among the growers, earnest endenvour on the part of each member, and enthusiastic and well trained leaders, the success of the movement is
sesured.

Unselfshness-Selfishness is a relic of a primitive civilization. Enough remains howerer, to make it a disturbing element in everyday life. One of the main charms of modern social life is unselfishness, but the ordinary methods of business appear to have no place for it. Co-operation, on the other hand, endeavours tw eliminate selfahness and its success depends largely upon the extent to which this is accomplishel. No co-operative acsociation can possibly succeed if the members are determined to act upon the ethics of ordinary business methods. If the few who have power in all association erercise that power for selfish ends, then there can be no real co-operation; and though rules and regulations may be carefully drawn up to offer no temptation to the selfishly inclined, yet after all is said and done we must, in a large measure rely upon the broad moral education of the members rather than upon direct and diatinet prohibition. Have by-laws and regulations by all means, but it shoull be understood among the members that there is a higher code of morality than can
possibly be embodied in these.

It is for this reason that the co-operative methods limit the dividends that may be paid to capital and exclude share voting. In ordinary joint stock companies, the influence and power is proportional to the money invested. so that the rich become richer by appropriating selfishly, through the power of money, the fruits of the labours of others, the unearned increment of values created by socicty, and the naturnl resources that in justice should be shared in due proportion by everyone. Co-operation distributes wealth in propurtion to the just carning of each worker, prevents the accumulation uf large profits, and shares unselfishly all uatural resources.

\section{LEADERSHIP.}

The apple growers of Canada are ready for co-operntion. They are far from being fully informed upon the far-reaching effects of the co-nperative movement and far indeed from feeling with full force the spirit which should aninate true co-operators. Nevertheless, they are alive to the-vast significance of the movement in other countries. and they are also impressed with the success which has so far attended the co-operative marketing of apples in our own country. Those who arr clncest in touch with the Canadian fruit growers realize that what is ueeded most at the present moment is wise leadership in each locality. A few men at least in eaeh neighbourhood are fairly well grounded in the social problems that affect ngriculture. In every agricultural 
district there is a wealth of knowledge and public apirit unosganized, which might be applied uncler wise guidance to the problems of that particular locality. It is not $n$ much trade investigator as sympathetio leaders that are needed aud the importance of these leaders at the present juncture can hardly b over-etimated. There may bo fifty farmers in a neighbourhood, all of whom would make excellent member of a co-operative society, not as blind followers of a leader, hut as intelligent co-workers, yet among those fifty it is very often impossible to find a single nan possessing the ability and combination of rirtues that go to make up the gualifications and character of the succeesful leader. Those who have the co-nperative movenent most at heart cannot do better than organize some means whereby lealers may be trained to help in this good work.

\section{CO-OPERATION IN PRACTICE.}

Yanagemert and Control. - The principles of co-operntion are fer and extremely vimple. Nevertheless, co-operators experimented for many years hefore evolving them and acting on them with confidence. Perhaps the main reasons for this are their simplicity and the fact that they are fundamentally opposed to ordinary bueiness methods.

Ordinary conmercial associations, whether they are partuerships or joint stock compauies, are formed for the purpose of securing dividends from the partnership or company. Co-operative associations are formed, not for the purpose of securing dividends through the association, but for the purpose of beuefitting the industry.

Joint stock companies, banks, loau associations and business partnerships are essentially autocratic. In these institutious the great majority of the shareholders take little or no part in the association. Co-operative assovintions are essentially democratic. The management is in the hands of the members.

In ordinary business associations voting is upon a moner bnsis, and the men with the largest moneyed interest control the affairs of the assorintion. In co-operative ausociations eaeh menber has a rote and no member more thall one vote. To still further guard against the concentration of power in the hands of one man or a few men, no proxies are allowed.

In commercial or industrial concerns no linit is placel upon the amount of remuneration received by eapital, and eapital is employed for the sole purpose of Eecuring this remuneration in the form of dividends. In co-operative associations the nmount that is earned by capital is as strictly limited and as definitely stated before it is engaged as the wages of employees, aud capital is used not for the purpose of eceuring diridends, but for the purpose of earrying on the business.

In competitive business, capital is master; in co-operative associntions it is the servant.

Division of Profits.-Nothing marks the difference betweun co-operative associations and joint stock companies so clearly as the division of profits. In an ordinary business association, if it should appenr, as the result of the year's business, that there was a surplus of $\$ 10,000$ after paying all just debts and making a proper allowance for depreciation of property, a distribution would take place in direct proportion to the capital invested and the amonut which eaeh memler would receive would be announced as a percentage on the stock whieh he held. It would be called a $6,7,8$ or 10 per cent dividend. In a co-operative association the mode of distributing this $\$ 10,000$ would be altogether different. $\Lambda$ n account would be kept of the use each menbrr made of the association. This would be represented in the ease of an apple association by the quantity of fruit sold for him by the association.

To make thic matter clearer let us take the case of tliree minulers of an appleselling joint stoek compauy. Mr. A. a well-wisher of the associntion, perhnps, but a pure investor, puts in a thousand dnllars of capital. Mr. B. an investor with a small orehard yielding 200 barrels, also invests a thousand dollars. Mr. C, hnring a large 
Orehard yledding 2,000 barrole has only enough ready money to justly him puttlng ln a hundred dollors capital. Let us suppose also that cepital can be obtalned at $\delta$ per cont and that the ascociation apples net $\$ 2$ per barrel. Under these clrcum. on hises A rould receive $\$ 50$ an dividend on his capital; $B$ would reeive $\$ 50$ divldend dividents and 400 on his apples, or 450 in all; $\mathrm{C}$ would recelve for capltal (1)

Now, it eon be understood that with such men as Mr. A and Mr. B ir tho assneiation, the directors might very easily put forward arguments that eapital snould receive 10 per cent. and as they are roting by shares it might require very for men thinking that way to force this decision on the company and yet kecp the price of upples above that of owlinary competitive buyers. Let us suppose that this policy has been adopted and that the inerense on capital dividends reduces the returns for apples to $\$ 1.75$ per-barrel. In all probability this could be done and yet the $\$ 1.75$ would be higher,than the price of apples obtalued by growers outslde the asoocintion. The distribution now would be quite different. Mr. A would rerolve $\$ 100$ diridend on his enpital or double his former receipte; Mr. B would receive $\$ 100$ on his eapital, but only $\$ 250$ for his apples. His total returne, however, would still be the came, 450 . Mr. C, being practieally a grower only, would receive 85 more on his stock, but 8000
les, for his apples.

The pure capitalist has his income doubled. The income of the small orchard enpitalist remains the same, but the producer suffers loss of 405 . And it was the apples owned by him and those who are similarly aituated that mado it posiblo to have a dividend at all. If the machinery of incorporation enables few men to appropriate all the advantages of co-operation, a very grave injustice is done to the
industry.

The above example is purel,y hypothetical, but even more striking cases might be given from the history of several defunet fruit associations in Ontario, which for obvinus reasons are not mentionel.

It is evident that grave dangers lurk in the joiut stock principle when applied to farmers' organizations. The joint stock prineiple in quite suitable to a company of investors, but to force it on a group of producers often works a great hardship.

\section{THE PRESENT SYSTEM OF PACKING AND SELLING.} namely:

The usual methods of selling apples may be elassed for eriticism under four heade,

1st. The grower of the fruit may pick, pack and sell on his own account or thraugh a commission merchant. 2nd. The grower sells by the barrel, picking the fruit. the buyer doing the grad-
ing and packing.

3rd. The grower sells by the barrel on the tree, the buyer doing the pieking, grading and packing. 4th. The grower sells by the lump, the buyer, of course, pieking, packing and
gruding the fruit.

The first method does not enable a sufficient quantity of fruit to be gathered together to impress the market. The expense of securing a suitable market ind the inipossibility of a single grower being sure that he has reached the best market, renders this method impracticable except for local markets.

The second and third methods permit a larger quantity of fruit heing gathered under one brand with some degree of uniformity, but the degree of uniformity is not sufficient to constitute a brand and the cost of harvesting and reaching the market is excessive. Of course this cost must ultimatrly be borne by the grower.

Sclling by the barrel, where the buyer does the packing and grading, is soldom satisfactory to either the buyer or the grower. It is almost impossible to so fix st andards before the packing is done that there will not be a'large margin for misunder- 
stunding botween the buyer and the grower. It not infrequentls bappena that the buyce will set very high standard for his No. 1's and 2's, with the reonlt that the arower finds himself with a large number of culls on hand, and comparatively for No. 1's and No. 2's. Uounlly thew' eulls, no matter bow good they may be, find a very poor market, if ther are not entirely wasted. The presunnption is, of enume, that these extre arades are shippod by the buyer to special customem, where they realise a price mueb above the averape.

On the other hund. the buyers are often deceived by their own workusen. These workmen may be presounl friculs of the grower or the urower nny. and often does, eajok the workmau liaving rhurge of the packing in put in "I poorer yuality of fruit than the arade calls for. The buyer having confitence in his unen frevuently ships these without inspection, und suffers the conserjuenee in having to muke a rebate to his customer or it mny be to pay a fine under the Inspertion und sule Art. If the grower wishes to sell by the barrel the more satisfactory wisy is for hill to offer the apples for sule in burrels graded by himself.

The fourth method most in rogue in Outario, has little to remonnmenul it. The buyer is of necessity better informed than the grower to estimate the junntity of fruit on the trees, beeanse his faenlties have been shurpened by yeurs of experienes in buying orchards of different rarieties and at different times. The arower, therofore, is not on equal terms with the buyer.

Unfortunately, there is no profituble outlet, as the trudo is at present orgmized, for low grade apples, and the temptation to work off as unany as possible of these in 'lump' bought orchards is often too strong to be resisted. The Donninion Fruit Inspectors now regard the fact that apples were packed in a 'lump' bought urchurd as sufficient reason for exainining them, and experience shows that there is an abnormal number of fraudulently packed apples from this source.

\section{SELLING THROUGH COMMISSION AGENTS.}

The selling methode so far eonsidered have all presumed that the frnit was sold to a buser who came to the fruit growers. Ontario apples are sold almost exelusively in this way. There are a fow, however, especially of tho larger growers, who coneign their fruit to commission merchants in distant cities. II Nova Seotia it las heen much nore coninon for individual growers to cousign on coinuission. A small arıny of agents could alwaye be found there, most of them representing English conimiasion merchants. Selling on comınission has proved a most unsatisfuctory wuy of disposing of the fruit erop, but until co-operative organization is much more complete than it is at the present time, selling on commission will be a necessury evil.

The perishable nature of fruit and the uncertainty in the quality and quantity of it until it is packed for unarket, nuakes it very diffienlt for individual growers to aell except by consigmment. Consigning fruit is a necessary evil us the fruit trude is now organized. One of the objects of co-operation is to do away to as grent all extent as possible with this method of selling. It is perfectly true that there are nuany reputable commission merchnnts whose record for fair dealing is unimpeachuble, but it is ubsolutely impossible for the individual fruit grower to determine whether or not he has been fairly dealt with. He cannot audit the accounts nor follow his fruit to the consumer, and practically he is obliged to take the word of the comnission man for all facts connected with the sale of his fruit. He simply places the fruit in the hands of his commission agent unconditionslly, and it would be strange indeed if some cominission men did not yield to the temptation and send returns below those recoived for tlie fruit.

It is not a question of the finaneial standing of the commission merehant. Ilis standing may be high, but if he wishes to be dishonest he need not want for a plausible excuse to return almost any sum to the grower. 


\section{SIORTC JMINGS OY INDIVIDUAL GROWERS.}

But it must not be suppowed that all the fraud under noul-co-operative mothoda in pruetivel by the conumiation men. Linfortunately many erowere are as fraudulontly inclined in their methode of packing and doing business an it is posaible to be. Weli diapoed merchants from the Northwent have time and asain attempted to deal limetly with krowers, and there are many eames where such arrangenents have been fairly satinfuctory fur a time. Apart frou all fraudulent intent, it is extremely diffcult for even the inrpest rrower to supply the needs of even a small retail busi. nesw overy jear, and with all the varicties required. Ilence such conuections are irrekular and have never proved mermanently satimfactury to eitlicr dealer or grower. But 1. A there heen perfect honewty on the part of the growcrs, even this irregular trade ould have been a great advunce on the ordinary modes of selling. Unfortunatoly, however, the dealers found a creat unany growers whose park coull not be trunted. It was simply impossible to investignte the character of every man from whom apples wore bought. and after the fraud wias discovered it was nsivally impossible to get any
redress.

Co-operation anong the growers of upples for the purpose of selling will remedy mont of these evils, but they could be almost completely wiped out if thero was co-oper. ation among the consumers as well as among the growern of farm produce.

\section{CO-OPERATION AND THE FRUIT MEROHANT}

Co-operative associations, therefore, do not aim to sell to the individual conouncr. The process is too slcw. But all good cooperator hope that the time will cunie when the consumers will be so organized that the producers' applo celling assosi. ations can deal directly with the consumers' distributing associations. But this ideal coulition of things is set far in the future, and until the consumers are better organ. izel. the cu-operative apple velling associations appreciate the fact that they cannot coune into contact with consumers in large numbers except throngh the fruit merchant
and retailer.

\section{CO-OPERATIVE ASSOCIATIONS AND YEW MARLETS.}

it may le well here to empinasize the fact that private dealers do not as a rule dive'op new markets. This devclopinent requires time and moncy. Both of these thir fruit nerchants are loth to give, and in most cases it must be almitted that it is reldom an indiridual merchant can hope to reap an adcuunte reward for a large outlay in the development of new markets. This work properly belongs to the fruit growers, with what aid and assistance they can get from the consumers concerned. No better use ctur be made of a surplus stock than applying it to the developn. nt of new mar. kets. It is a common experience thut after a year of extraordinary production in fruit and consequent low prices, the demand in many quarters has increased. Market invelopment is the rork of fruit growers as a whole, and thus falls under the class of work that can be done by a union of co-operative associations better than in any other way.

This is not merely u matter of theory. The best orgunized selling co-operative

ciations have recognized the development of markets as a most important part of their work, and large quantities of surplus fruit are frequently used for this purpose by such associations as the California Fruit Exchange and Georgia Peach Growery' Exchange.

In 1908 many of the young peaply orchards of Ceorgia, that had been planted during the peach planting bonm a few years before, came into bcaring. The growers were not organized and the crop went through the usual c: vels to the large fruit distributing centres, with the result that the commision men were overwhelmed 
With frult, eapociall! un certaln days, and as nelther the merchants nor the consumers anticlpated 10 heavy a stock much of tho fmilt was onld at ruinous prlees, and comen of it could not be sold at all and was finally condemned by the bealth authorltles. $\Delta$ t the

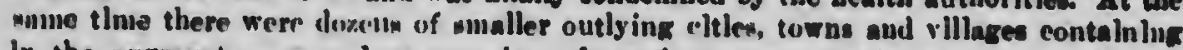
In the aggregate a very large number of peach consumen, who had an lnoutiolont supply of frult of had none. Belng a perlahable commodity no time was afforded for communicatioa between the diatributling centren and those ontlyiug tr.rus. It is Invdleas, to say that the returns to the peach groweers in Georgla were extremely dis. apirointing. Nerertheless, It had thls good effect, that it proved boyoud quentlon thit some Improvenent munt be made in the mode of selling Georria peaches. The following year the cro is still larger, more or hands bad come into beariug, and it wn a good pench year. But in the menutisne the peach aruwers were thoroughly orranlzed Into co-operative assoclatlons with a central selling assceiation, and hundreds of enrloads were earefully routed, so that the larre dlstrlbutlug centren recelved only what they could consume; and 18 there whs a surplus, one or inore cars were sent to arcents who liad been selectel in thene munller towns nud villages, where an independent buyer would not have risked so perlshable a consignment. The result was that, althongh the crop was nearly doublch, there was no glut of Georgin peaches upon the market the cecond sear, and a large number of new markets were openeil un $t$ practically 110 cost to the fruit growers, inasmuch as shese sinaller town usua... ade a fair return for the frult shipped them for the first time. This incident is only one of scores thant might be cited to einphasize the fact that 'sluts' can be aroidel only af the grourern' rnd. Jierchants caul d. little to prevent gluts and are eveu inore belpless in turning an orer supply to any gond account.

\section{MARLET RFQUIRE.MENTS.}

Though the arevage fruit grower may be quite compotent to meet the needs of the local market, the case is ruite different when it comes to the long listance and the export market. Complications arise in these markets that render it practicully impossible for single arowers to compete with success. In the local market it is larely a question of the individual buyer catering in small quantitien to the likes and dislikes of single iudividuals. For the long distanec and the export trade the requirements are altogether different. Among these none are more inportant than thri following. namely,

1. Large lots of iruit,

2. Few rarieties.

3. Uniform packing, grading and marking which implies:

4. Skilled labour retained for the most part from year to ycar.

The unlerlying principle in ail these is uniformity. and uniformity is asked to mable merchants to deal in large quantities. Skilled labour is neceesary to ensure this.

\section{CO-OPERATION II PLODICTION AND MARKFTING.}

For the ordinary methods with which we have been dealing, it is proposed to substitute co-operation in packing as well as in sclling, and incidently in any other phase of apple growing that will lend itself readily to this mode of operation.

The following advantages will be gained:

(1) Large stocks will be controlled by sellers who will act as n uuit.

(2) Uuiform packing, grading and marking will be prqcticed.

(3) A reputation associated with a permanent brand or trade mark will be established.

(4) The cost of picking, :- $\quad \cdot 1$ marketing will be redlunvl.

372:30-3 
(6) Frult will be plokert and paoked at the proper tlene

(b) Ino common variotici can be shipped profitably.

(7) By-products cun be utilized.

(8) Btoring faeilltice will be better prorlded for.

(8) Direct elling at the point of productlon will be encourased.

(10) Packnnw will be bought In lare quantitles or manufactured on the preminen with a material reduetlon lu coot.

(11) The co-operative uee of opraylng apparatus or other expensive orchard laplements will be encournsed.

(18) The purely cominerilal part of the Induatry will be plecod In the bands of the mont compotent men whose Interents are ldentleal with those of the other membere of the axcoclation.

(13) The manager and botter arowers among the patrons will have overy Induceuneut to atimulate the lass pmerensive momluen to better work.

1. 1) Fapilities for oxiendlng eredit or making each adranrem can be easily and (-hinply furulobed to fruit arowern.

(16) The distrlbutive sides of co-operation even beyond orchnrl supplles will be encourased.

Inre Quantitien-The Influence of what morchants call 'long llnes' is seldom appreciated by the indivldual crowes. The ent of selling is almost an grent for a sunall quantity of produce a for a larse. Where each iudivldual frult grower makee hin own shlpments, these inas vary from two or three barrels to. perhaps, two or three hundred, but the ennaller number is much moro common than the larger. It la necessary, therefore, for the merchant In celling, to open a sample of each bi aud and make - suecial eflort in the sale of this brand. This takes time which mue: be paid for out of the proceeds of the frult. It also injures the frult to a certain extent. Thla $t_{.} .2$ becomes a charge. Hence the adrantage of co-operative asecelations with a common brand and a uniform ayotem of grading.

But when we approach the larcer markete of the world there are always mexchants whose trade calls for axtraordinary quantitles of fruit. It costs those merchants a large sum of mones to argregate this from the ordinary small-lot consignments. If, then, thes have an opportmuity of setting this extrandinary quantity of fruit in one lot, thes are willing to pay an adranced price for it and save themselves at least some' of the cost of aggregating small lots. For this reason, as well as for many others, it is always advisable for the individual co-operative associations to unite as aon as they are nimerous enough, into large bodies, and thus secure ns lapp. a aggregation of fruit as possible.

Oniformity in Paoking and Grading.-Of course the value of a large stock is lost to a great cxtent if the sanple is not perfectly uniform throughout. As the size of a co-operative association increases, the diffieulty inereases in keeping the brand unifurm. A co-operntive association should be limited to the unuber of members that furnish a unit for a single overseer. Hence also the necessity of adopting the central packing house system where the packing will be done by a single gang of packers. Uniform!n, in pruding and packing adds very la rucly to the price of goods cuite independent of its intrinsic merits.

The Reputation of a Brand.-There is a quick recognition in the markets of the world of brands that are t'niformly wall pucked and such brands have a value quite apart from the merits of the fruit. $A$ ease in point is that of an Ontario dealer doing a large business in the better grades. He had graduated from the employ of a good apple packer, and when he started in business for limself, gave five cents per barrel for the privilege of using his emplojer's braud. Thouph he has paid his old employer thousands of dollars for the use of his brand it is only a small amount compared with what manj growers are making or losing as the nesult of reputation. 
Co-ep retive Melleds and Branda-There lo a difleuity, of eoures, in maintaiuing a ligh staniant of brand. Tht difilenlty is much grenter in the cas of a private ludividuai than in the case of a copprative acochation. A privite individual hes every incentlve to trade upon his repulation oner it is made, and uniem he is partioularly conscientious and atrong-minder is is apt to overlook certain defecta in the fruit that place it bolow the otandand of the brand uniler whlch it is ahippod. liuler co-operative methods then is no unch lurentive; it is rather tive other way. Tive manager is prond of bis brund and has everytbins to loce and nothing to gain by linwerlue this standurd. Ile owns uone of the fruit but he has bis own reputation to maintain and this cas only be done by maintainlne the reputation of the braud. liuder the central packing house syotem he has direet jerroul ovrmight of all the work of the parken and thus it enablod to enforee uniformity not only for a ungle season but from year to jrar. It is not too much to any that the extruordinary primes proeuret hy the arowers of fruit on the Pacifie Conat are the resuit iargoly of a reputation for perfect uniformity in grading and markiug. It must be added, how. over, that only anod fruit is shipped, but the quality teuted by the eye or by the palate is certainly uot better than the fruit krown in the east, graded with the same curs. If there were un otice inducements than simply the securing and preservation of i reputation for a brund, co-operation wouid justify itself.

Economy in Farverting and Marketias.-The aystem practiced in Ontario by private deulers is mout extravagant. It is celdom that a buyer can sceure all tho orchards ill a perticular nolghbouriood. More frequeutly the orcherdn of any particular buyer ore weparated by iong distances. Since all the growern will not pick their fruit, the buyen are obiiged to keep gangs of pickers and packen. At thi. ceason of the year labour ls particuiarly wenre and applo packers have found it impossible to secure the kind of labour they would iike. They are obliged, however, to take what they can set, and it is no slauder to say that the latwirr mecured is fur from being efficient.

The transportation of thesc gangs from orchard to orchard takes time and is otherwise very expensive. Rainy weuther intorvenes, when the apple buycr is obliged to pay heavy expenses for board bills with no work whatcver going Gll, Fven with his lest endeavours grave miatakes wili be nade, the cost of which must ultimately depress the price which the apple buyer can pay. The apple buyer also is not slow to auert that where orchards are bonght the grower not infr'suently fails to protect the fruit between the saie aud picking time, and thus add a s.. her formidable loss which falls upon the price of the fruit.

It is not too much to say that the fruit could be picked and packed by the grower of the fruit for one-half what it costs the ordi:: ary apple dealer.

Picking Fruit when it is Mature.-One of the sources of trouble with pueked apples is to be fund in the fact that the varieties ure not picked at the proper time. Under the old gystem of it:..rant buyers this evil was a most pronouneed one. The packer could not usnally afford to visit the orrhard morc than once, and twice would be asceptional. In the meantime certain varietics of apples had become over-mature. Oiher varietics were picked before they were quitc ripe. inasmuch as another visit cuuld not be inade. The pucking of immature fruit and over-ripe fruit, often in the ame lot of apples, accounts for many cases of poor condition at the market end.

Under the co-operative method this evil mas be corrected. Varieties are taken just as they moture without extra cost, and there is no temptation to pack inmuature apples.

Utilizing Special Varieties-In many of the older orchards a great variety of apples were planted and so long as the grower used only the local market this proved an advantage, but for shipping purposes these odd varieties proved very detrimental. Mauy shippers allowed them to remain on the tree, rather than break a brand for : few barrels of this variety or that.

$37230-34$ 
The Colvert.-Under co-operative methorls many of these varieties have become excoedingly valuable. A case in point is the Colvert apple in Western Ontario. The Colvert is a prolific apple, of excellent quality and, though uot as attractive in colour as a red apple, is rery acceptable where it is known and where it can be obtained in good condition. The ordinairy apple buyer, however, found that there were too few in any one orchard to make it worth his attention. They were rather soft to ship with full or winter apples and so usually proved a loss to the grower. With the establishment of co-operative associntions the Colvert has become one of the most valuable varieties for its season.

The Gravenstein.-It is not at all unlikely that co-operative incthods have given - new lease of life to the Nora Scotia Gravenstein. For many ycars before the establishment of co-operation in Nova Scotia the Gravenstein, for several reasous, was falling into disrepute with the growers. Coming as it does carly in the season and demanding the very closest attention in pieking, packing and shipping, the ordinary methods of private dealers seldom proved satisfactory so tlut, although the "puality of the fruit was unsurpassed, it did not prove profitable. Under co-operative methods all this is changed. The picking is done at the proper time, the packing is better, the shipping is inuch more prompt, and the markets are better prepared, so that the fruit gocs into consumption immediately, when it is at its bect. $\Delta s$ it is now handled by the co-operative associations it is likely to prove oue of vic best paying varieties that Nova Scotians can grow.

By-products.-Anoug the unany advantuges of eo-operation not the least is the opportunity to utilizs the lower grades of frnit and culls a.s a marketable product. $A_{\mathrm{s}}$ the orchard business in Canada has been conducted in the past, what are ordinarily known as the waste products have indeed been a positive waste, and it is not ton much to say that if the by-products of the orchard had been mannged as successfully as the by-products of the meat packing industry, the results would have been equally satisfactory. The orchards of Canada should be turning out, in adlition to the choice sreen fruit, large quantities of canned apples, apple jelly, evnnorated apples, cider and cider vinegar.

Improvement in the Grade of Green Frnit.-The advantages would not all be put under the head of mere 'saving.' If ther' wh canned or evaporated prolucts for the lower grades of fruit, there is no doubt whatcver that a much closer grading would be the result. No. 3's would practically dis"lupear from the publie markets, and a better grading of No. 1 and No. 2 would soon be istablished.

Luder the old nethods of marketing Canadian apples it was practically injpossible to utilize economically the orchard by-products. There are a few evaporators and a small quantity of cider is made, and some eider vinegar, but none of these prody cumand the highest position in the open market. Our evaporated apples bel ug almost exclusively to the lower grades, and our production of eider and cider vinegar is so small in quantity as seareely to make a showing.

Association and By-product Factories. - Under co-operative methods conditions will be mueh inproved. Privately owned evaporators, eanning factories, ete., ur. undoubtedly of some advantage to fruit growers, but the lower grndes of apples aml thi culls will never be utilized to the greatest advantage, both as regards the financial returns to the producers und the quality of the product, until ull these establishments are owned by co-operative assoristions. It is only then that the supply can be definitely calculated upon and the quantity of it definitely known. Onc of the first effects of the establishment of evaporators, for instance, woull be the manufaeture of the lighest grade of eraporated fruit. For this it would he necessary to use the very highest grade of No. 3, or possibly a large part of what is now packel as No. 2. There would be no temptation, if evaporators were extablisherl at nll convenient apple-ship- 
ins points, to use anything but the highest grade of No. 1 and No. 2 as green fruit, inamouch as the lower grades would probably bring a higher price as extra choice waporated stock than they would as green fruit in barrels.

Unfortunatels the great advantage in this is not jet thoroughly understood by our apple growers, and there is a reluetance on the part of associations to undertake what they regard as an outside line of husines, involving considerable expense. In this, however, they are mistaken. We have enough examples of eo-operatively nanaged evaporator and canning factories to show that the adrantakes in this line are quite as great $a$ in the shipping end of this husiness. The funancing of this enterprise should not be a difficult matter, once growers have confidence in their ow institutions. A comparatively small amount of ready cash supplied by the growers would induce outside capital to come in at a moderate rate of intercst.

Storage Facilities.-No feature demonstrates the value of eo-operation better than the establishment of storage facilities at the point of production. It is rery true that in Nova Scotia and Ontario large warehouses were put up by private dealer that were an accommodation to the growers, but in all such cases a heavy toll was exacted, if not directly by way of a storage fee, then indirectly in the control which the warehouse owner obtained over the selling of the fruit. Many private growers found it advantageous to put up warehouses of their own; smaller growcre, however, could not do this. By co-operative methods one or more storehouses are built that accommodate the fruit of all members. The same accommodation furnished in a number of small houses, built by individual growers would, of course, cost considerably more than one built large enough to accommodate the fruit of the whole association. Such a warehouse is always open for the reception of fruit and $i$, usually eonveniently situated for shipping it.

Warehouses in Nova Scotia.-The co-operative associations of Nora Seotia have appreciated the value of warehouses and nearly every onc of the societies has erected its central packing house. The popular size is 100 by 40 feet with a basement and attic for storage. Such a warehouge will store 10,000 barrels of apples and will accommodate quite easily a crop of from 20,000 to 25,000 barrels. Great improrements have been made lately in the matter of insulation. Tentilation also receives more eareful attention. The cost of such warehouses will vary according to the local price of material from $\$ 3,000$ to $\$ 3,500$. Some larger warehouses are being built 150 by 40 , with a reduction, of course, in cost in proportion to the storage capacity. So far all the warehouses liave been built of wood. It is just possible that, where lumber is very dear, briek or eonerete would be the cheaper matcrial.

Improved Tethods of Selling.- Enough has already been said to show the very grent advantages, in a general way, of selling collectively. Onc or two points, howercr, may be still further emphasized. It nust be admitted that when the best has been done it is difficult to designate the quality of apples with perfect nccuracy by a graile: mark. It must be admitted, also, that the contingencies of shipping are too numerous to be definitely foreseen and estimated. It is therefore partionlnrly important that the huyer and seller should meet at the point of production. This is made possible hy co-operative selling. Even a single association will aceumulate chough fruit to uttract buycrs in sufficient numbers to secure competition. In this way any differenec of opinion with reference to the quality of the apples can be settled on the spot when Inth buyer and seller are present, leaving no rom for misrejresentations and rebates as is too often the case where the fruit is accepted only at the marliet end.

Packages.-Fruit growers use large intantities of parknges. Indeed in few lines of fruitgrowing is the eost of the packages less than twinty per cent of the gro:s proceeds. It is then apparent how important it is that this end of the business be clowely watehed. Private growers cannot always secure tlu-ir parkages convenicutly. At best each must give a small order with the result thit hizh prices provail. By 
co-operative methods these small orders are assembled into one large rder, with very great economy in the buying. This econony is an easential one. It is an advantage to the cooper or the basket maker, inasmuch as it enables him to place his order for stock early in the season, enables him to hire men and keep them at work during the usual slack seasons, and it nlso does away with any losses by bad debts.

Many associations have gone a step further and manufacture their own packages. A set of cooper's tools for making apple barrels costs from $\$ 20$ to $\$ 75$, according to how elaborate the fixings may be. Any existing building having a large floor space, will do, with very little change, for a cooper shop, and men may be employed during the slaek months, and barrels may be manufactured here any time diring the year. Not only does this enable the growers to obtain their packages somewhat cheaper than they could get them from a cooper, but it also helps to solve the problem of labour on the fruit farm. Aly intelligent labourer on the farm can soon be taught to nake an apple barrel as well as the ordinary cooper. In winter time and on stormy days when work outside is impossible, these men can be employed inside.

Purchasing and Uaing Implements in Common.-The orchardist is subject to heavy expenses for implements, spray material, and general repairs. These can seldom be purchased by private indivin aals satisfactorily. Prices to individual growers of course must be retail prices, with frequently very heavy profits added. Dealers, trusting to the chance purchases of individual growers, can not accurately estimate the number of implements or the quantity of material required, and to be on the safe side usually order less than the nceds of the neighbourhood, with the consequence that soine one is short. But the experience of the last few years has shown that co-operative associations can reduce the cost for implements 15 to 30 per cent, and a very great reduction is made by soveral neighbours using a single high pricerl machine instead of each purchasing for himself.

Securing Expert Business Men.-It is scarcely to be expected that every fruitgrower should excel as a business main. Not the least of the advantages of co-operation is the fact that the best business ability can be secured for the purely commercial end of the industry. The adrantages of this are self-evident. A man may be a most excellent grower of fruit, but it would be phenomenal indeed if he could form a proper judgment of markets and prices, without an expenditure of time and money totally disproportionate to the value of his crop. The same time and noner expended by the Manager of the Association would enable him to sell the products, not only of one
association but of sereral associations.

Educational Valne.-Perhaps no single featurc of co-operative work lias conluced inore to the benefit of the industry than the educational work that is beim donc. Under the old system there was little incentive on the part of anyone except the grower to improve the product. The buyer was not sure of being able to secure any particular orchard a second rear, and so he wasted no time in giving instructions; the better elass of growers did not come particularly in contact with other growers in such a way that they could bring any pressure to bear upon them for improvement. All this, however, is changed under co-operative methods. In properly unanaged association, the manager is constantly on the alert to avail himself of every means of sweuring better fruit. His reputation as a manager is at stake and for this renson he has a definite interest in the improvement of the brand. It has become the practice of nearly all the associations to issue special literature giving instruetions in the care of orchards. Denionstrations are arranged for in spraying and the more backward members are urged by their fellow growers to improve their methods in order that the gnmeral hrand may be as ligh as possible. Every feature of the business is an incentive to the grower of the poorer grades to rench the standand of the better growers. The effect of this is very marked. Many examples could be 
giren where orchards that yielded a comparatively small sum of money before the adrent of co-operative associations have greatly increased in output and in the quality of the fruit so that the revellue is sometimer quadrupled.

Canh $\Delta$ drances.- In looking over the difficulties that have beset existing cooperative associations, few have been so serious as the necessity of making advanoes upon fruit that is being shipped. Unfortunately many of our apple growers are not forehanded in the matter of money. There can always be found private dealers who, in consideration of a reduced price, will buy apples for ready money and there is a strong temptation on the part of rnany growers to accept this lower price for the sake of securing casin. It is the duty of co-operntive associations to meet the necessities of these men. In the incorporation of the companies, however, provision is seldom made for a large capital for immediate use, most of them depending upon the returns from the apples to meet their needs. In the case of many fruit growers this is satisfactory enough, but fails completely where help is most needed. It must be accepted. therefore, that part of the work of every association is to act as a credit association for the convenience of its members. This can be done easily if the directors will proceed in a business-like way.

Although co-operative associations are not yet sufficiently well established to command capital from ordinary banks upun the credit of the association alone, yst there are few associations where the personal note of the directors will not be accepted for any reasonable amount as security for an advance. The directors in this case, laving charge of the business of the association, run no risk whatever. They regulate the advance up to a sufe limit on the quantity of fruit shipped by each meniber. Such an arrangement has been worked satisfactorily for many years by several of the associations, and in no case lias any director or anyone connected with the association, lost a cent by these transactions. Sinple as the process is, a great many of the associations have lost valuable members hecause they failed to provide for their legitimate and reasonable finaucial demands.

Distributive Co-operation.-Distributive co-operation has become a strong feature among a few apple selling associations in Canada though the great majority have made little use of the organizations for this purpose. This is particularly trie with reference to Ontario, where the associations are widely separated, preventing any constant interchange of ideas and phr:\%. Another cause is that many associations are not large enough to get the full soyit of buying in wholesale lots. Nev(r. theless there seems to be no good reason why distributive co-operation should not be extended till it includes practically all the supplies that onchardists need.

St. Catharines Cold Storage and Forkarding Compan,.,-An exception must be made among Ontario societics in the case of this associacion which is one of the older societies and from small beginnings lias become one of the largest. It has been fortunate in having a munager more than ordinarily intelligent and public spirited. The following is a list of the supplics distributed by this association in 1912:-

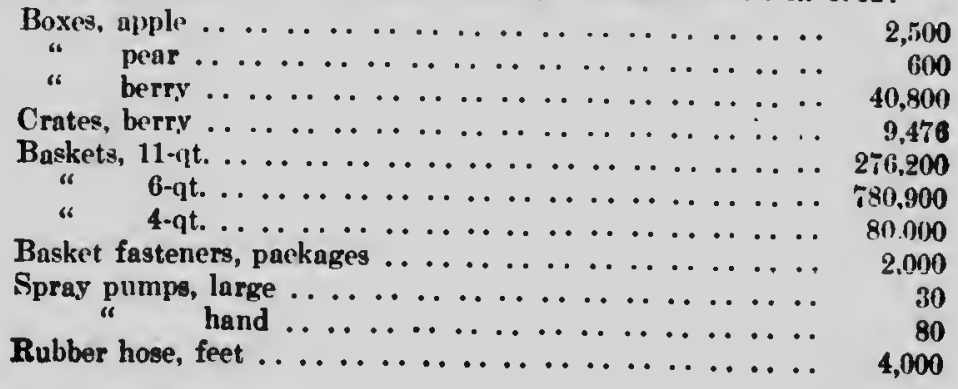




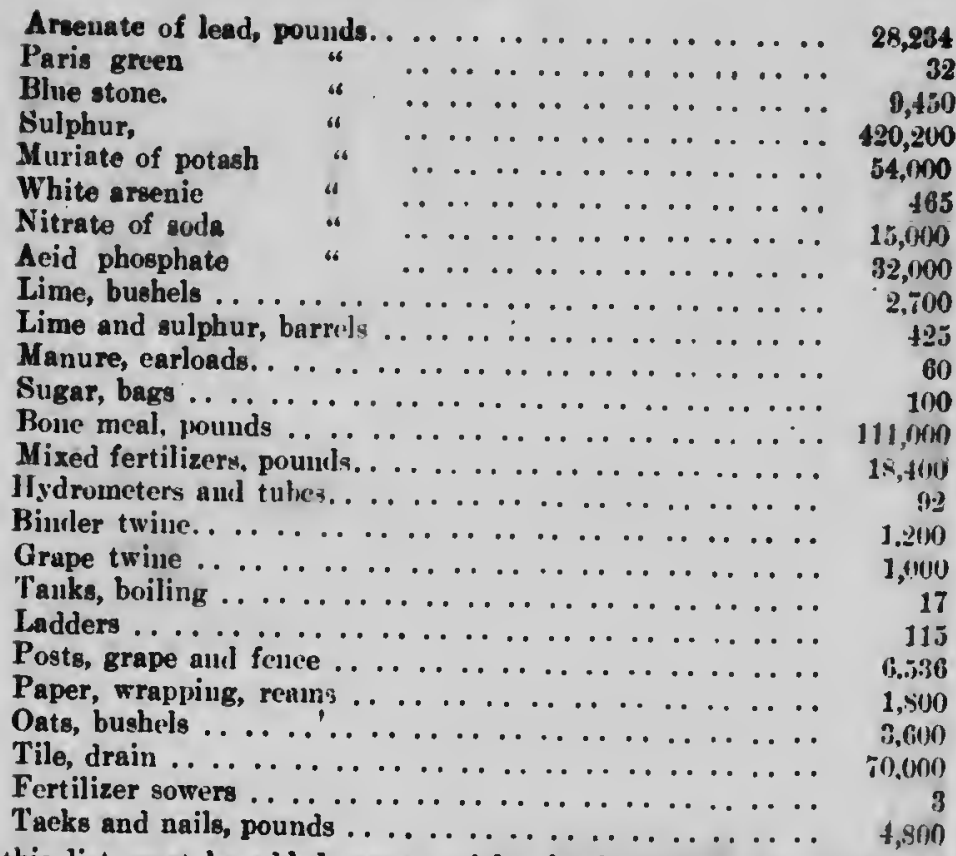

To this list must be added many articles for houschold use, purclinaed through the association in wholesale quantities. The ralue of supplics distributed in 1912, would aggregat a about $\$ 75,000$. The manager estiniated thiat the members of the association have saved in one year, by purchasing in this way, not less than $\$ 15,000$.

The Iabour Problem.-During the season of 1011 the associations of Nora Seotia had a most forcible demonstrntion of the ralue of co-operntive cffort in solving the labour problem. They had an extraordinary erop of nearly two millicn barrels, which is twice the normal erop for the prorince. As will be inferred, when picking time came few people were prepared for the emergency. If each indiridual grower had beell obliged to provide for his own labour, it is not too much to say that a very large percentage of the crop would have been lost for want of help to pick and pack at the proper time. But the. Central Association came to the reseue of the indiridual growers by advertizing in the labour centres for a small army of pickers, and the result was that the labour difficulties were not at all serious. Even if the growers would hare secured these labourers individually the cost would hare becll many times as great. As it was, few of the growers belonging to the co-operntive associntions had any
labour diffeulties.

\section{BENFFITS TO OTHERS THAN MliMERS.}

One of the satisfuctory things in conneetion with the apple selling co-operative movement is the influence which it las upon the trade gencrully. The eo-operative associations have undoubtedly improred the quality of the apple pack, and at the same time they hare secured a higher price for their apples than coull hare been obtained by individuals. But these adrantages are not eonfined to members of associations. Others have benefited greatly in the matter of price througl the work of these organizations. The Norfolk County Fruit Growers' Association, for instance, has put up an excellent pack and has received prices much above the average. The effect has been to increase the price of all sples that enu cliaim to ho Norfolk County apples. 


\section{THE RISE IN TAND VALUFS.}

In many eases the price of the orchard lands has increased rery rapidly as the result of the work of these associations. The value of the erehard land in the neigh. bourhood of St. Catharines, Onturio, has at least doubled. Thase who are thoroughly competent to form an opinion npon this matter assert that this is due, in a large measure, to the work of the St. Catharines association, and if it is so, this association is a inost valuahle asset to the neighlihourhood.

The County of Norfolk is anether example of the power oi fruit sclling asmociations to benctit a neighbourhom 'This county is one of seseral bordering on the north shore of Lake Frie and it is no disparagement to say that it possesses no edvantages in the matter of soil and climate over any of the other counties in that tier. Y't the value of fruit land in Norfolk county, quality for quality, is much higher than in the other counties that do not possess co-operative associations.

It is difficult to say just what co-operation has done for the value of real eatate in the three principal fruit growine counties of Nova Scotia: Hants, Kings and Annapolis, but the fact remains that there has never been so rapid an increase in the value of real estatc as has taken place since the organization of en-operative associations in recent years.

The effect of co-operative associations is equally marked in British Columbia, where 75 per cent of the fruit is now handled co-operatircly

\section{SUGGESTIONS WITH REFERENCE TO ORGANIZATION.}

Forming an Amociation.-The details of orgunizing m association are comparatively simple. After the whole matter has been diseussed in an informal way among those who are interested, a meeting is called to elect the necessary officers. The rofteer usually selecterl consist of the presideint, rice-president, secretarytreasurer, and tive or more directors. At this stage the secretary slould write to the l'rovincial Department of Agriculture for details in the matter of sccuring a charter. Fill information will be given as to the procelure, step by step, t:ntil the charter is olitained. The expense of this is very slight. After receiving a charter the association is then ready for business.

The office of secretary and irensiner is often combines.

In a small assoriation it is usurlly better to combine the oftice of the secretary and manager. The manager creates the correspondence and lins time in a amall scciety to attend to all the sceretarial work.

Officers should not be selected except for ability in the line of work required ly. the position.

In the case of a large nssociation it is often better to hire an outside man als manager, in which case the engugement should be a yearly onc.

Guarantee Bonds.- In all the larger as-ociations any official hanlling money ehould be required to fumis? bonds. In most cases the guarantee of two or three good men in the neiglibourhoml may be acepted, but ordinarily it is better to secure a guarantee bond from some corporation making sperialty of this lusiness.

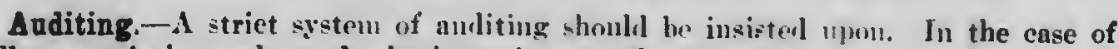
smaller associations where the business is somewhat linired, some nembers of the association will, in all probability, be qu ite competent to act as anditors. But usually in cases of this kind the business should be put in such a form that prery incmber of the association mar hnow the receipts and expenditure in consideralle detail. In the case of a larger association it is better to call int an expert aceountant to make a yearly audit. The cost of this is not larre. It gires well dispested me'mbers " further con'Jence in their association and effectually stops a great deal of pernicious criticism .ely to grow up aven in a well conducted association, where there is not the utmost blicity. 
Membership.-As far as possible every asoociation should open its doos to the widest possible membership. Neverthelos, it is seldom satisfactory to secure members by over-persuasion. It is a great mistake to think that all the large growers of a district must be in the association in order to make it a success. It is usually desir"'lle that the large growers should be in the association of the neighbourhood, but as they are likely to benefit lese immediatcly than the smaller growers, they are sometimes loath to join. Not infrequently it is better that large growers do not associate with the smalle: growers.

Equality of Interesta. - The ideal aimed at in every association should be to have members with equal interests in every way. It is exceedingly difficult in some cases to harmonize the interests of a inan who has five acres of orchard with the interests of the man who has a hundred acres. It is often better to form two associations in II neiglibourliond if there is a sufficient number of two distinet classes of groivers. Sunall growers may unite in one association and the larger growers in another. There should be no difficulty in harmonizing the interests of these associations in that case. Of course it is understood that this recommendation is made only where the organizations are conducterl in the spirit of mutual helpfulness. Sueh associations caus conduct much of their buviness as one association. In the California orange districts it is not uncommon to have three or four co-operative associations at a sirgle shipping station, in some instanees, occupying a common building. In these sssociations there is not a semblanee of rivalry except the friendly rivalry of each association to outdo the other in benefitting the industry. The spirit of selfishness is just as reprehensible in an association as in an individual, but its power for evil is vastly multiplied.

Ontside Dealing.-One rule that should be considered fundamental in all associations is that members must sell all their fruit of a special kind through the association. In the carly history of the associations it was thought impracticable to draw the line too close with reference to this and almost without exception an amendment had to be nuacle to the rules. It was found that growers who were allowed to sell some of their fruit outside of the association and some of it through the associntion, sometimes at least took advantage of this arrangement to the detriment of the interests of other nembers of the association. If the higler grades were sold by private sale and then the rest of the fruit 'pooled' with the association fruit, there was a manifest injustice. Better exclude a member altogether than allow him to sell any fruit without the permission of the association.

Association Assets.-One of the difficultics in connection with co-operative associations, especially the smaller associations, is to hold the members together from year to year. An important factor in tbis connection is tbe acquiring by the association of a certain anount of assets. This can be either as paid-up capitnl and in cash, or it may take the form of investment in warehouses, evaporators or other appliances for the use of the assoeiation. This gives the association a stability that it would not otherwise have, and it should be the aim of those who wish the movement suecess to secure these hostages to continued membership as early as possihle in the history of the association.

Co-operative Bookkeeping.-Co-operative bookkeeping cloes not differ in general prineiples from hookkceping of any other kind. Many associations, however, will have their bookkeeping done by those who have had little experience in book keeping involving the interests of others. To such it nay be said that every naterial fact should be a matter of record. Contraets should be in writing. Verbal agreements should be confirmed by letters. An entry should be made immediately of money naid and received. Receints noting exact amounts nf quantities should be takell and given for money or produce interehanged. Whenever a transaction is at all complicated a written statement of all the faets sbould le on record in addition to the bare entries in the regular accouts. 
It will usually bo found that much time is saved and inore satisfuctury work is done by having printed forms for receipts, stock lists, packing table records, etc. II the case of receipts for fruit they may bo padded so that a carbon paper between two leaves will give duplicates, one of which can be filed at the office and the other given to the patron.

It will usually pay an association to consult an expert accountant who will sug. gest books and forms to suit the apecial needs of the circumstauces. Each association has something peculiar in ite mode of working that meeds a special provision, but un', device will take the place of conscientious carefulness on the part of the bookkeeper and a record of all material facts.

Incorporation. - Of course, it is quite possible to do a eo-operative business witl.out ineorporation. Where the inembers have perfect confidence in cach other and where the business is not complieated, the assoeiation can often be condueted just as well without ineorporation as with it. It is, lowever, a dangerous mode of conductinu business where large amounts of money are concerned, where liabilities are incurrel, and where the menbers are not familiar in detail with each other's affairs. Such uII nssoriation would, in all probability, be regarded at law as a kind of partuership wheru each onc would be responsible for the aets of the association as a whole. It might be cyen posible for some indisereet member to ineur liabilities involving rather ineon. venient consequences. It is urged, therefore, that every association seek ineorporation. The advantages are numerous. The liability is linited to the anount of stocis lield. No member ean ereate for another a liability. The association can suc and ba sued without trouble or inconvenience to the members, and responsibility is placerl upon individuals who can be held accountable.

\section{CENTRAL PAClílNG HOUSE.}

In the earlier history of the co-operative associutions the central packing house was not usually adopted. It was the almost universal custoin for eaeh farmer to taks his fruit, graded and packed by himself, to a warehouse at the railroad stution where tho manager of the association assembled the different varieties and aralles and shipper in carload lots or quantities to suit his purehasers. It was very soon found, however, that while this improved the uniformity of the paek somewhat, it still left a great deal to be desired. This is not due always to fraudulent intent on the part of the members, althongh it must be adinitted that there were few associations practieing this method that did not count among their memlers some who were frandulently inclined. Nevertheless, with the best intention it was simply impossible to get 10 , 15 or, perhaps, 50 growers to observe the same standard, with a suffieicit degree of uniformity to meet the needs of the market. To overcolne this difficulty the eeutral packing house system has been adopted by practically all the newer co-operative assoations.

The central paeking house system eonsists in having a common warelouse, usually at a shipping station where the apples can be loaded on a siding. The apples are brought from the orehard in barrels mulheaded or, if headed, unpressed. It is abs, lutely necessary that they should be drawn to the packing house on spring wagons, although a fer of the sinalker growers substitute for a spring wagon the ordinary hay raek filled level with hay or straw. On this the apples are placed and carry with comparatire safety. These are delivered to the eentral packing house and a receipt is taken. In the eentral paeking house a gang of expert paekers are employed who have no knowledge of whose apples they are packing. The result is that the apples of the whlole assuciation pass through the hands of a single set of graders $\varepsilon$.d uniformity is sccured.

Many growers who have not given this matter proper cousideration objeet to having the grading of their fruit taken out of their liands. Nerertheless. it must be admited that few men can be trusted to pack their own fruit. Of eourse the inore intelligent 
bo fruit mowen an the more capable they are of psekind. their own fruit. Yet even amone Exowers so intelligent an those in Hood Piver; Oregon, the expert packers of the smociation grade and pack all the fruit. I neer unt 80 into the reasons for this. Ipon the moral side, I think it will be admitted that fruit growers, on the average, are conotituted with enough selfishnes to induce them to look om." themeelvee, and the line between looking out for themeelres and giving tha public a pro. perly packed box of apples, is so indintinet that people who acir own upples often yield to the temptation of overitepping the mark. On the oiner hand, men who aro employed to pack up to a certain otandard and who are working de bs das with apples belonging to many different owners, whow fruit they do not dintinguish and in whom they hare no special interest, have no temptation to srade below the proper limito. There is also a purely economic reason for adopting the central packing house aystem: individuals who pack and do nothing else become extremely expert at thin work and can do more and better work, and so not only reduce the cont of production but actually improve the grade of the product.

In the case of early apples and soft fruits that will not admit of being readily taken to a central packing house, an alternative plan is adopted, namely, eending the central association expert paokers to pack the fruit in the orchard of the grower. A combination of the two system is found to work satisfactorily in the Norfolk Fruit (Growers' Association, where the ereater part of the fruit is packed in the central warehouse but, in addition, expert packers from the central packing house, are aent to put up the fruit of gowen in certain outlying orchards.

\section{CENTRAL ASSOCIATIONS.}

Single associations are experiencing some of the evils that formerly met private ahippers. They find that a single association is not large enough to cope with the problem of selling fruit in the distant or in the foreign market. This has led to the formation of unions of local associations. This form of organization has beell found absolutely essential in the marketing of citrus fruits in California, and the Califonia Fruit Growers' Association may be taken as a good type for organization. The membership is composed exelusively of associations, and the business is confined ontirely to the selling end. All details with reference to the fruit up to the time it in ready for market are left in the hands of the local associations. Of course, precautions are taken to enforce proper grading and marking. In this way it is powsible to place this, the most intricate part of the business end of fruit growing. in the control of experts who are in the employ of the association. Owing to the large quantity of fruit under a single control, such a central association has great puwer in regulating the supply for different markets and thus increase the conoumption as well as improves the price to the grower. They are able, also, to cope with many problems too large for a single association, such as questions of transportution and distribution in foreign markets.

The United Fruit Companien.-The best example we have in Canada of a central selling association is the United Fruit Companics of Nova Scotia. The incmbership of this company consists of co-operative associations operating in the Anuapolis and Cornwallis valleys. They operated for the first year with a very imperfect organization in 1910. In 1011, the organization was much better and did splendid work under most adverse conditions. The crop of Nova Scotia was a phenomenal one. A large crop was expected, but even the most sanguine calculations were exceeded by 25 per cent. In all probability there were not less than two million barrels grown in Nova Scotia in 1911, nearly three times the average crop. The transportation companies were unprepared for the task of moving this enormous erop and serious conwuences threatened. Fortunately, however, the central association was sufficicntly organized to materially assist in the work. In the early part of the season, sooll after 
the main crop bergan to more, it was found that there were hundreds of carloads of apples in the jards at IIalifax sweltering in the lint sun. with the ateamuhip eaparity entirely taken up. Of course, these apples could not remain in the jarda long without cerious detriment to the fruit und as a temporary remedy tho asociation succeded is inducing the railway to send out four solid train losds of apples to Montreal, connecting there with the ceean steamshipe lenving for European porta. This, however, proved only a temporary relief, and the managers of the co-uperative association: proceeded to Ameriean ports and chartered four steamship that were loaded immerliately and sent to Europe, earrying altogether somethiug over forty thousand barrele of npples. This relieved the situation grently, and it is not too mueh to say that had it not been for the efforts of the central association thousands, if not tens of thousands of barrels, would have rotted in the orehards for laek of transportation facilitien. No private dealer, nor any probable combination of private dealers, eould have solved this transportation problem as did the United Fruit Companice.

The usual markets for Nova Seotia fruit would have been greatly over suppliel if the older market methols only had been used. 'The eo-operative anaciation. however, seut agents to the Northi and sold muny thousands of barrels in a markit never before supplied by Nova Seotia fruit. They also sueceeded in opening up a large direct trade with Germany, selling the dealers there nearly one hundred thousand
barrels of apples.

This is sufficieut to illustrate the great value of a central association. Without it the Northwest market could not have been exploited eren by the strongest single association, nor could the (iernum market hare been opened up.

On the distributive side the centrul association lins proved that it is able to make Ereat saving in orchard supplies. One of the la rkest itens in the rumning of Nora Beotin orehards is the fertilizer bill. The central associution bought for their.patrous in 1011-12, nearly fifty thousand dollars worth of fertilizer. The saring upon this was t3 war ton, or a total of $\$ 6,000$. It should be emphasized here that this saving could not have been made by the associntions working separately. The fertilizer compauies macle a determined effort to maintain the system of sales through local agents. This they could have done if they had had to deal with inclividuals or individual associations. It would have been a ease of a uniterl arnoy of fertilizer inanufacturers against muorganizel fruit growers or of small organizations. The frtit growers would have leen beaten in detail. The United Fruit Cumpanieg with their superior organization won out, but not without a hard struggle.

\section{ORGANIZATION AMONG EXISTINi ONTARIO ASSOCIATIONS.}

As has bien noted, co-operation such as we have annong our apple sellers, is in its details a local development. It was not a eomplete system imposed from without, but sinuly a gencral idea, the development of which eame from the fruit growers themselves. Under these circunstances it is but 11atural to expert that the form of organization would be almost as various as the number of societies. One of the largest and most suecessful eo-operative associations in Ontario is not incorporated. Officers are elected at the beginning of the year, and each senson's busines is elosed and disposed of and the association nominally disbanded.

Other associations make provisiun for continuity of existence without being ineorporated. The officers hold their positions until their sueeessors are eleeted, but the business is praetieally eondueted in the name of the nunager or some other individual.

In a few cases a amall numiver of growers have united as a joint stock coinnany, -and this company own the warelouses and other property. 'They liave, howerer. a general organization that ineludes all growers that work, so to sluenk, in harnony with 
the jolnt otock company. Thl pecullar arranement was adopted by an Ontarlo cocloty that for ceveral years worked quile succenafully, but unfortunatoly a large quantity of the ntock was hold by towappeople who were not rrowers, but were interented in promoting the adrancement of the nolghbourhood. The splrit of dirldead-making erept into the management. The rental for the warehouse whlch was owued by the company and the expenses as determlned by the company, were conshlered too lanse by some of the growers. The diseatisfaction opread and finally the company, composed larkejy of nou-producers, found itelf with a warehouse and uobody uning it. The company, of course, went into lijuidation. Unfortuuately the fruit growers acociated this mismanagenent with co-operation and no efforts have heen ouccessul since in eutablishlng a purely co-operative selling association in that ncishbourhood. It lo quite probable, howerer, that with the aumerous examples now it ezistence of sucresoful co-operative assoclations, several places similurly situated will organize again but on better lines. Practically all the ouccesful asaocin. tions in Ontarlo that are incorporated, are simply joint stock companies and they owe their aucces to the fact that the infueatial members have adhered to cooperative methods as far as possible and have not taken advantage of the powers which joint otock incorporation gives them to tum the ansociation into a dividend-making concern. Indeed one or two of the aceociation have gone to the other extreme and hare paid no dividends on the capital invested. Thls, howerer, was so manifestly unfair to a few indiriduals who had fumished capital much beyond the areraxe, that part of the proceeds of the business is now distributed as dirideuls upon the stock limiterl to 5 per cent.

\section{CO-OPLR.ATIVE LEGISLATION.}

None of the provinces have special Acts that provide for otrictly co-operative incorporation. There are, however, means by which farmers' associutions caul be incorporated. New Brunswick and Ontario have encls a joint stork company Act which, however suitable for industrial concerns, is not at all suitable fur co-operative
purposes.

The Prince Edward Islaul Association was incorporated ly an Aet of the lo al legislature. The Nova Scotian Act for the Iucorporntion of Farmers Associations is drawn up along the lines of the usual jnint stock company organization and is of courace objectionable on that ureount. It, loweres. serves the purpose fairly wisll.

The United Fruit Companies of Nova Scotia was organized cooperatively by un. Special Act of the local legislature. Quebec has an Act under which farmers' associations can incorporate with some co-operative features, but with share votin. The Act for Incorporated Farmers' Associatious in British Columbia permitz associations to organize coureniently on the joint stock principle.

\section{PROPAGANDA.}

A most notuble feature of English distributive co-operation is the very large sum of ninncy devoted to educational purposes. In the ycar 1910 this amounted in round numbers to one hundred thousand dollars. When the societics rere few and the wholesale organization was struggling for existence, it was of vital importance to organize more socicties. But now that the societies have become numerous and the wholesale society unasaailably strong, little individual benefit can come either to the societies or their members by new, organizations. The educational fund of the British co-operators is conceived in the purest benevolence and with a cordial recognition of co-operative fraternity.

In the case of Canadian apple selling assuciatious we do not need to appeal to this spirit of altruism alone. Further organization is absolutely essential for the material interests of the industry. The uumcrous plantings that have been made in British Columbia of late years are now beginning to put fruit upon the market. 
Outario's output is Inereasing rapidly and Nova Bcotia la cortain, under the otiusulus of her co-operative ormanleatlon, to continue planting at an lnervaned pate. It must not be fo: sotten, toa, that there has been an equally viguroun revival of apple wrowink In the Vinited States Imniedintely to the south of us, and it is but natilal to expect still larger quantities of fruit frosu thle source. For market purnowes the applo crops of the United Btaten nnd Cannda is practleal:s one. There is ourplus for export in both reuntries and both countries aro looking to the same forelgn narketa an outlete for thin auplus. If wo do not meet the compretition of Anurican srown apples in Winuipes, Basktoon, Regiua, Calram or Fduonton we must certainly meet it in Liverpool, Glaszow, London and IIa sburg. Success will come to the best onganizvl forces. British Columbia, Nova Seotia and Ontario will meet In competition within our own borders, and without organization amone the apple growem many of th" wornt features of competitive hujing and selling wlll be intensified. A frank menmi. tion of the community of interest in these three provincs, at leant, rill go far to insuring the continued prosperity of the apple industry, notwlthatan ing arratl. increaserl productlon. This happy state of affuir eas unly come about by a thorough organization of the growers in each prorince. It is apparent, thercfore, that Nova Mcotia with her fr:-ly efficicut orgunization is vitally interested in the thorough co-operative organization of British Cblumbia and Ontario, and just as each provinc"s! is Intereated in the thorongh organization of aii otlem, no communities that havo the advantage of loenl ussociations, arm vitaliy interented in having every other part of the province equally well orkanized.

For this purpose each local association should devote a certain percentage of it a returus to the edicational or propaganda fund, and every effort should be mado to plan carefully the expenditure of this fund. Co-operative markctiug will not how its full effect until the apple growers of the Dominiou are organizel from the Atlantic: to tho Pacific.

\section{APPENDICES.}

T.e forms for Constitution and By-laws givon in $\Lambda$ ppendix I are aimply sug. gestive. Local couditions should be consulted. In matters of detail considerahle latitude may be allowed to personal prejudices, within the limits of the governing legislation. There are usually many ways of accomplishing the saine object, and any rigid adherence to a set of words or to a particular method is likely to introduc, friction. As far as possible it is recommended, of course, that the co-operative fcatures
be safeguarded.

Attention is diroted to the By-lawg of the Forest Fruitgrowers' Associntion. They are simple, direct und linve worked satisfuctorily. The By-laws and Constit!ltion of the Norfolk Fruitgrowcrs' Association are quite suitable for most suall associations which are confined exclusively to apple selling. The Constitution and By-laws of the Islaud \& Cypsun ciruit Company contuin features that will be of intercat to associntions that inteud to have mixed shipments of fruit, and where tho output from the diffurent members varies greatly in quantity.

Spccial attention is directed also to the model by-lawis recommended by the Department of Agriculture for Ontario. It will be noted that clauses 26 to 24 provisls a rery convenient mechanism for raising money on capital account. If this mcchanism is ndopted, and if the association is organized under the general clause of the Company's Aet for Non-Share Capital Stock Associations, there is no rcason why Outario associations should not be strictly co-uperative. that is, the by-laws uniglit ensure a fixed remuneration for capital, one man, nue vote (there would be no shares) and the distribution of any surplus on the bagis of the valin of the business dono by the member of the asgraciation. This device, although not, conrenient nor so safe as the best co-operative legislation of European countries is yet butter than that of any of the other provinces. Guarantee notes, however, may be adopted in any of the provinces in lieu of share capital. 


\section{APtido 1. \\ TORFOLK FRUIT OROWERS' ABSOCIATION.}

\section{CONETrTUTIOS AND BY-LAWE.}

1. This Amoviatlon shall be known as the Norfolk Frult Growers' Amociatlon.

9. The object of this Aewociation ahall be to encourage the lruit Growers in the county of Norfolk who are interented in the improvement of the gualliy and quantity of Fruit, to co-operate for the purpose of cocuring a better and nore unlform aystem of packing and marketing of thelr Frulta.

8. Any pernon In the County of Norfolk in the frult-growing Induntry and is recommended by the Executive Committee, mas become a niesuber by paylng to the Becretary-Trealurer the sum of One Dollar, on or befure the Fint day of April in ans year, and such payment olall entitle such perwon to all the rights and privlleges of membermip the onsulns year.

4. The Anuual Meeting of the Ascociation shall be beld on the first Wedneeday in February of each year, at such place as the Aswociatlon may select. The Business of the Annual Yeetiug aball be the reelving and disposing of the Auditor's Annunl Report upon the butinees of the preceding year, the Aunual Election of Oficen and ouch other buvines as may be brought forward by the bixecutive Commitice.

6. All elections aball be by ballot, plurality electing, and shall be condueted by two scrutinces appointed by the chairman.

6. At the Annual Meeting five members ahall bo elected as an Exocutive Committee who will have the general management of the Association in buying, selling and any other buniness of importance. At any meeting of the Fiecutive Committee, thres all constitute a quorum for the traneaction of businees. Two Auditor shall also be elected at the Annual Meeting who are not members of the Breutive Collmittee. Three members not members of the Executive Cummo's shall also be elected at the Annual Meeting as Inventigation Committce, whose duty it will be to investigato all complaints.

7. Specia' meetings of the Association nay be beld at any time upon call of the President, by written notice mailed to each member at least five days before the meetine.

8. Special meetinge shall also be called by the President, whenever required to do $s 0$ in writing, by five per cent or more in number of the menbers of the Associn.
tion.

8. At any meeting of the Association 15 per cent in number of the member shall constitute a quorum for the transaction of business.

10. The Officers of the Association shall consist of a President, a Vice-President who shall be chosen by the Executive Committee from among themselves, at the first boand meeting after the Aunual Meeting, the Manager and Secretnry.Treasurer to be appointed by the Fxecutive Committee. Special meetings of the Executive Committee may be held at such times und places as they may select.

11. The President, or in his absuce, the Vice-President, shall preside at all meetings of the Association. In the absence of both, : chairman shall be chosen from the members present.

12. The Manager and Secretary.Treasurer for the Association shall have charge of the busineg in detail. but eannot clne any dealings tinlirss authorized to do so by the Executive Committee.

13. It will be the duty of each member to so care for lis or.harl as to froduce the rery best quality of fruit. 
11. All acod berreling apples aruwil by memben of the Amandations (exerpting for their own uee) are to be handlel by the Brecutive (oumuitter. and uny unenilue

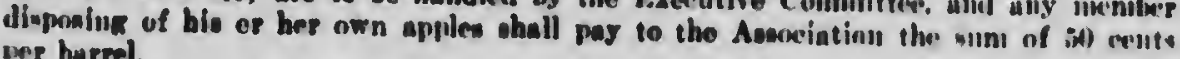
per burrel.

15. All nemben muset pack theis truit for shipnent In a neat workmanlike? malues, aud If auy member is not capuble of packing him npplen In thla manner he la

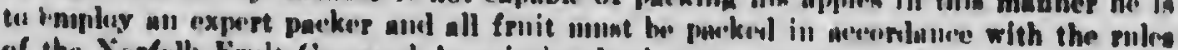

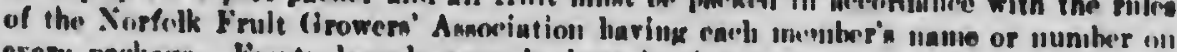
every parkake. binpty barrelo numbe be kept in the dry aul ulan all paekent burrols numt be plneed in the drg everg day in a well rentllated builling until ahipunent is muile.

16. Hach menibre must onder from the Secovingy all the barrels he will remuin for hle own ne not liter than Angunt int of pach yenr, same to be paid for la hill not later than Norember 10th.

17. Any menlape persinting in injurious conduet towards the Asmociatlon or uny

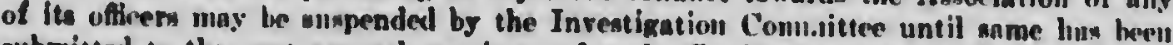
oubmittel to tho next peneral meetink and each offending member shall rereive threr

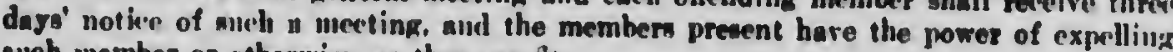
oneh member or otherwime, an they sec bit.

18. The bookn of the Ansociation thall be audited before the date of the anmuni meeting in earl, your, and the report of the rercipts nnd dimburwements, properly elened. whull be rend it such annual meeting. The members mas order a npweviul allit of the books to be made at anj time, and the Auditors shall report therern without unneressary delay.

10. When from nily ennse racnncy oceurs in any of the oftices of the $A$ xwexilltion, it shall be tlled by the Freeutire Committee at their next meeting. A hwoniw, without leave from three consecutive meetings of the Fxecutive Comnitte slunll ereate a vacuncy.

20. The Sernetary-'Treasurer ahall kexp a revord of the prexcevlings of all inmet. ings of the Assoeiation. or its Exeentive Committere of all meeipts und disburmenents, and he shall report the condition of the finsulees numully or ns often as the Bxerus.

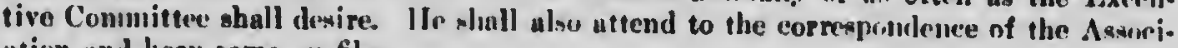
ution und keep same on file.

21. Fiery dispute between numbera and the Asxen-iation. of any perwun claimiug

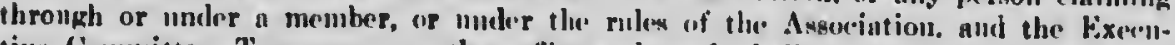

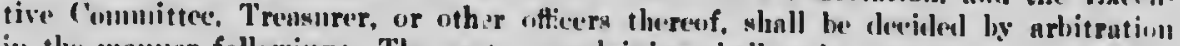
in the manner following: The paty complaining Nall make o stutement in writing

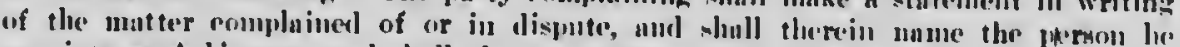

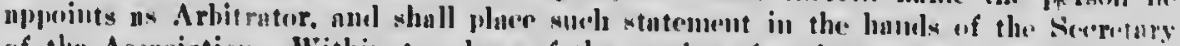

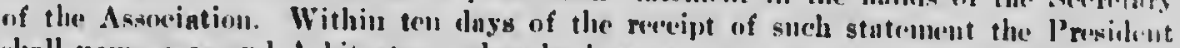

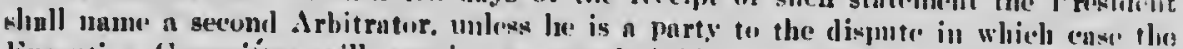
lixerntive Commitee will npwoint n scerond Arlitrator. The two Arbitrators will mect and appoint a thirl Arlitrutor. and the Arbitrntors sol appointerl shall umet without umeressary delay mul lieur and letermine the mutter in clispute. and file nu award with the Secretary of the Askouintion, which dwarl if sigued by nt least two of the Arbitrutors, slunli be bincling and couselusive on all partion without appeal. Nothing lerein eontained sluall be coustruesl to prevent buth parties agrecing upon one Arbitrutor, whose decisinn in such ense would be tinal. All Arbit metors appointed under this Saction must be sureulners of the Asxoriation.

22. These rules may be amended at any regular or special meeting by a rote of the members present. Notice of any proposed amenilment must be given euch member by letter or otherwise nt lenst ive lays previnus to the meeting. 


\title{
THE FORIST FRUIT GROWERS AND FORWARDING ASSOCIATION.
}

\author{
CONSTITL TION.
}

1. This Associntion of Fruit Growers shall be known as "The Forest Fruit ('rowrers and Forwarding Associution.'

2. The object of the Associntion is the better production and sale of fruit grown lyo its menlers.

3. The Annual Meeting of the members of the Association shall be on the first Mlonday in December in each year. Special Mectings una be held at any time upon the eall of the President by written notice.

4. At the Annual Meeting the Directors of the Association shall be elected.

5. At any meeting of the Directors a two-thirds representation of the Directors shal' constitute a quorum for the transaction of business.

6. The Offieers of the Association shall consist of a President, Vice-President and Secretary-Treasurer.

7. Iminediately after the Anuual Meeting and the election of Directors it shall be the duty of the Directors to eleet Offeers as named in by-law six, the President and Viec-President to be chosen from the Directors.

8. The President or in his absence the Viee-President sliall preside at all meetings, of the Assoeiation. In the absence of both a presiding offieer shall be chosen from those present.

9. The Secretary-Treasurer shall keep a reeord of the proceedings of all meetings of the Directors and the Association. He shall also keep a reeord of all the receipts
and disbursements of the Association.

10. Any Fruit Grower within a radius of eight miles of Forest shall be eligible to becoune a member by a two-thirds vote of the Directors of the Association.

11. The constitution or by-laws may be amended at any regular or special meeting upon u two-thirds vote of the Directors.

\section{THE FOREST FRUIT GROWERS AND FORWARDING ASSOCIATION.}

BY-L.IWS.

1. The Board of Dircetors shall meet semi-montlly or monthly or at the call of the President, sueh meetings not later than July 1st of each year.

2. It shall be the duty of all offieers to attend regular or special meetings of the Assoeiation and hold offiee until their sueeessors shall be eleeted.

3. When a vaeaney shall happen by death or resignation in any of the offices, it shall be filled at the next regular or special meeting.

4. At the annual meeting of the Assoeiation in eaeh year the President shall render a statement of the business of the season in full.

5. Fach and every member of the Association shall piek his fruit in prine condition and deliver same ut Paeking House or shipping p.int.

ii. Aı Inspeetor or Manager of the Association shall be appointed by the Direetors to supervise the work of grading and paeking of the fruit of the Assoeiation, the salary of the said Inspector to be deterinined at the time of appointment.

7. The Manager shall give persunal instruetions in their orehards to every shipper shipping through the Assoeiation how to grade and mark their fruit according to the Fruit Marks Aet.

8. That he wil see to the ordering of and securing of ears, and will obtain whatever neeessary Re_igerator ears, whieh he sces are properly iced.

9. He shall keep in constant communication with the Salesman, and shall receire orders and eonmunicate them to the members of the Association.

10. He shall see to the making up of Car Lots and notifying members when to pack and deliver fruit at Packing House or shipping point. 
11. Ho thall keep a record of name and graue or truit of each shipper in each car and forward a copy to purchaser.

12. He shall also inspect a certain number of each shipper's barrels in each car and immediately before shipment in order to ascertain if the Fruit Mark Act has been carried out, and if he finds that any shipper has intentionally disobejed the Fruit Iurks Aet he shall be rofused acceptance of fruit and held responsible for

13. It is azrer. i that shipper shall be responsible for space ordered in ear whether $i$, fill it or $n^{*}$

it. If the In wetor disagrees with shippers regarding grade apples, for the settle$n$ :. it of such dis" areement he shall choose one Director, the shipper one Director and both Jointiy was disinterested person, who shall decide, basing their decision on the Fruit Marks Act.

15. All charges for ieing cars to be paid heforc car leaves, such charges to be colleeted by a lewy on each barrel the car contains.

16. Fach and every menber shall have the right to give away such fruit of his own raising as he may clect, but he shall not make salc of fruit outside the Association except windfalls and cull grades or any fruit that may not be accepted by the $\Lambda_{s, s i-}$ ciation. Any member so doing shall pay into the Association treasury the sum of 50 ceuts per barrel for all fruit so sold excepting grades aforesaid.

17. Whenever in the cpinion of the Dirertors it is impossible for the Association to receive at its packing huuse all fruit grown by its menbers, they may pernit individual members to grade and pack the same for shipment througl the Association, such grading and packing to be subject to the inspection of the Inspector appointed by
the Association.

18. All members of the Association shall spray their orchards at least four times and as often berond that as they deem proper.

19. No fruit grower shall be admitted as a member of the Association exeept by a two-thirds rote of the Directors.

\section{KELOWNA FARMERS' EXCHANGE (LIMITED).}

CONSTITLTIO. AND BY-LAWS.

1. The objeet of the Kelowna Farmers' Exelınge is the marketing of all kinds of produce grown by the Members of the Exchange.

2. The points of shipment for the produce sliall be deeided upon by Members of the Exchange.

3. At the Annual Meeting the Members shall elect a board of 5 (five) Directors, who shall at their first ineeting elect the President, Vice-President, and 2nd VieePresident from their number.

4. The Directors shall be elected annually by ballot and shall hold office for one year unless removed for cause.

5. Any Director may be removed from office at any time for any cause when twothirds majority of the Members of the Exchange consider the removal of such Director in the best insterests of the Exshange. In the crent of such renoval of a Director, the vacancy so made shall be filled by the election of another Dircetor hy ballot at the same meeting, for the unexpired term of office.

6. The general work of the Exchange shall be carried on by a Seeretary, chosen by the Directors, whose work shall be.the general managenent of the Fxclinige, the soliciting of orders, over-seeing the receiving of produce and inspecting the same, loading of cars for shipment, keeping of accounts, and shall receire all sums of muncy due or payable to the Exchange, and shall deposit all moncys received in some cliartered Bank, approved of by the Board of Directors; no puyinent to be made withont the written order of the Secretary-Treasurer and the President, or in the casc of his absence, of 
the Vice-President, or in his absence of the 2ud Vice-l'resident; rivi due notice of ceedings of same; write all letters of Board of Directors; keep a recurd of all procorrespondence; slaall keep copies of the name of the Association and conduct its

7. That the books of the and one rpecified day of tho werke be open to inspection of Directors at all times.

8. The Secretary sliall be reyuired to give bonds to an amount gat isfactory to the
Board of Directors.

9. Each member shall have a number or unark, which shall be placed ou every sack, box, crate, or other parcel or thing shipped by him. The Uirentors shall decirle
how such mark shall be placed.

10. All produce for shipment shall be inspected before shipment, aud if any produce is not good quality and in good condition for shipping, such produce shull be anted or otherwise prepared for shipment at the expense of the party to whom such

11. A fund shall be created by assessment on each sale to cover all losses by frost, transportation, or bad debts, or any other eause, not due to the shipper.

12. Payment for produce will be made to the shippers on the receipt by the Exehange of returus for the sale of their produce, unless otherwise ordered by the full
Board of Directors.

13. In case of there being more of a certain class of produce on hand than the orders for such produce for the time being demand, each inember shall, as far as the proper filling of orders and convenience of shippers will permit, ship proportionate
mounts.

14. No Member's claim for shipment of proluce shall be considered uuless such produce shall be delivered at the detemuined point of shipnent, has been inspected and found fit for shipment, or has been prepared for slipment as provided for in
rule 10.

15. The standard of yuality repuired in produce and the condition in which it is to be delivered for shipnicut, including the kind and qunlity of the sacks, crates, boxes, or other packages used, shall br decided by the Board of Directors.

16. The amount of salary to be paid to the Secretary appointed under Rule $;$, shall be decided by the Bourd of Directors.

17. Three members of the Board of Directors shall form a quorum.

18. Any member of the Exchange obstructing the work of the Exchange, causing loss or inconrenience, may be suspended by the Serretary until such question shall have bean dealt with ' $J y$ the Board of Directors. Any nember agreeing with the representative of the IXxchange or the Board of Directors on the price he will take to the Exchange the refugal of the same.

19. All complaints must be made in writing to the Board of Directors.

20. Two Auditors shall be elected annually who shall audit the books and aecounts of the Exchange at the eud of the shipping season, or oftener if required by the
Board of Directors. 21. The value of each share in the Kelowna Farmers' Exchange shall be 85 , and
each member shall subscribe for not less than one share.

22. A meeting of Shareholders shall be called at any time to give the price which they are prepared to accept for their produce, and in no case shall it be deviated from
unless the Boarl of Dircetors see it is in the interests of all parties to do so.

23. The expense of the Exrhange shall ls met by a percentage on returns for produce sold by the Exchange, the anjount of such percentage to be decided by the
Board of Directors. 
24. A two-thirds majority rote of the members of the Exchange shall orer-rule any actioll or decision of the Directors, and any member may appeal from the decision of the Board of Directors to the Menbers of the Exchange. In such case the decision of the Board of Directors shall be final.

25. Any changes to these rules may be made by a two-thirds majority rote of the members of the Exchange, taken at a meeting ealled to consider such change, of which at least ten days' notice shall be given.

25 (a) A majority of the stock subscribed, upon which all legal calls or assess. melits are paid in full, shall constitute a quorum at any Shareholders' meeting. and no vote shall be counted which is not represented by one share of stock upon which all calls or asoessments have been prid.

25. (b) The Directors shall have power to lery and eollect assessments on the capital stock, the same to become delinquent in thirty days from day of notice in local paper of such assessment. The Nirectors may sell such delinquent stock at public auction to the highest bidder for cash, first giving thirty days' notice of such salc in a local newspaper, such sale to be mad 3 at the door of the office of the Exuhange.

25 (c) That no dividend of more than 5 per cent be paid on the stock of the Fxchange, any surplus funds to be applied to the running expenses of the Exchange. 25 (d) The President or Chairman shall vote upon all business, and shall have
110 casting vote or dual vote. 26. The annual meeting of the Kclowna Farmers' Exchange shall be held on the
first Monday in January in each year.

\section{CONSTITUTION AND BY-LAWS OF THE ISIAND AND GYPSUM FRUIT COMPANY, INCORPORATED UNDER THE IAWS OF OHIO. OAPI- TAL STOCK, $\$ 5,000$. ACT AMENDED JUNE 13TH, 1900.}

\section{CONSTITLTION.}

Section 1. This association of fruitgrowers, being incorporated under the laws of "io, shall be known as the Island and (iynsum Fruit Company, its capital stock

Section 2. The object of its organization is for the sale of the fruits grown by its members, also to buy and scll such fruits during the scason as opportunity presents.

Section 3. The annual meeting of the stockholders of this comprany shall be on the first Saturday in December of each year. Special meetings of the stockholders may be held at any time upon the call of the President by written notice mailed to cach stocklolder of record.

Scrtion 4. At the annual meeting of the etockliolders five Directors shall be

Section 5. At any meeting of the stockliolders a two-thirds representation of the tiock, either in person or by written proxy, shall constitute a quorum for the transac-
tion of business.

Section 6. The officers of the company shall consist of a President, Vice-President, Secretary and Treasurer.

Section 7. Immediately after the annual ineeting of the stockholders and Directors are elected, it whall be the duty of the Directors to clect the officers as named
in Sectio: 6 .

Section 8 . All elections of this company shall be by ballot, plurality electing, conducted by trio tellers, appointed by the President.

Section 9. The President, or in his absence, the Vice-President, shall preside at all niectings of the stockholders. In the absence of both, a presiding officer siall bo
chosen by the stcrkholders. 
Bection 10. The Secretary shall keep a recond of the proceedings of all the meetings of stockholders and directors, and shall recoive as remuneration the sum of for each and every meoting, when such services shall be duly rendered by said Secro-
tary.

Section 11. The Secretary shall keep a correct recond of all the receipts and disbursements and report the condition of the finances annually, or as often as the
Directors shall desire.

Section 12. The Directors may select not to exceed three of their number to act ns an Executive Committee (the President to serve as Chairman of this Fxecutive Committee), to have general eharge of the affairs of the corporation during the fruit season. This committee shall order all purchases of supplies. The Directors shall regulate the amount of compensation this eommittee shall receive.

Section 13. Any fruit grower in Ottawa County, this State, shall be eligible to become a member by a two-thirds vote of the stockholders of recond at the time the application is made, also, a two-thirds vote of members shall determine the value of each share of the stock that sueh party shall pay into the treasury, if he or she shall
be admitted as a member.

Section 14. The Constitution or By-laws may be amended at any regular or special meeting upon a vote of two-thirds of the stockholders or stock in the affirmative.

BY-LAWS.

Article 1. The Board of Directors, during any season when there is not a failure of fruit, shall meet in session semi-monthly, beginning such meetings not later than
July 15th of each year.

Article 2. The Executive Committee during the fruit season of each year, shall meet at least once a week, or oftoner if the interests of the company shall demand.

Article 3. The President shall have a general supervision of the business of the company.

Article 4. On or before the first of May of each year, when the fruit crop is not a failure, the Directors shall meet and name their Manager for the season.

Article 5. The Manager shall have charge of the business of the company in its detail, under the supervision of the President.

Article 6. Manager and Treasurer shall give bonds in such a sum as shall be acceptable to the Directors.

Article 7. The Treasurer shall receive all moneys from the Managcr and deposit the same in such bank to the credit of this eompany. Such depository of the funds to be designated by the Directors. The Treasurer shall check the same upon order from the President, countersigned by the Manager, of upon order from Manager, as may be directed by the Directors.

Article 8. It shall be the duty of all officers to attend all regular and special meetings of the cempany, and to hold office until their successors shall have been elected.

Article 9. When a vacancy shall happen, either by death or resignation in any of the offices established by the eonstitution or by-laws of the company, it shall be filled
at the next regular or special meeting

Article 10. At the annual meeting of the stockholders each year, the Manager shall render a statement of the business for the season in full.

Artiele 11. Any member of the company may withdraw at any time, between Deecmber or the first day of April. Sueh notice of withdrawal must bc given in writing to the President or any Director of this company. Thereafter it shall be the privilege of such retiring member to sell and dispose of his or her fruits as ther shall rlect, but this company shall not take or handle any of such member's fruit thereafter, during that season, unless it shall be determined by a two-thirds. vote of all members
in the affirmative. 
Article 12. In eonsideration of the several assessments whieh have been placod upon the preacnt stock of record, previous to 1900 , to each and every meinber holding such stock there shall be issued (gratis) another share $(\$ 50.00)$ for every share so hold.

Every member shipping not more than 5,000 bushels of fruit shall hold two thares (\$100.00) of the capital stock for increased output, follows:-

1 share for all over 3,000 bushels up to 5,500 .

1 share for all over 5,000 bushels up to 8,500 .

1 share for all over 8,500 bushels up to 12,000 .

1 share for all over 12,000 bushe' up to 16,000 .

1 share for all over 16,000 bushels up to 20,500 .

1 share for all over 20,500 bushels up to 25.500 .

1 share for all over 25,500 bushels up to $31,0 \mathrm{~m}$.

Article 13. The stock shall pay a dividend of $T$ per centum, less incidental expeuses, as repairs, insurance on buildings and taxes. This 7 per eentum shall be collected froin cach member's fruit account in proportion to the number of bushels of fruit with which each has been erediter.

Article 14. Dividends on stock, as provided for in the preceding article, shall not "nply in time of a failur" of fruit crop. In such times dividends shall be void.

Article 15. No transfer of stock shall be lawful unless duly reeorded upon the books of the company.

Article 16. All peaches, pears, plums and quinces grown by eaeh and every meinber of this conpany shall be delivered to the company's packing house for arading, packing and shipinent.

Grapes and other small fruits may be delivered to the eompany for sale or disposal, and shall be disposed of for the grower on commission of onc ecut per basket.

Article 17. Each and every member shall pick his fruit in prime condition and deliver same promptly to the eo: upany's packing lo'*e. In ease green ead immaturo fruit or overripe fruit, or windfalls, be delivered, any member, saine may be acceptel and said members shall be credited with average price such fruit may bring.

Article 18. Each and every member shall have the right to give away sueh fruit of his own raising as be or she may elect; but shall not scck, solicit or make sale of fruit outside of the eompany, excepting windfalls and cull grades of any fruit that may not be accepted by the company. Any member so doing shall pay into the company's treasury the sum of fifty cents per bushel for all such fruit sold, excepting sales of aforesaid grades.

Article 19. All fruit delivered each day shall be credited to the person furnishing the same at the arcrage price which the fruit brought that day.

One-third of the amount so eredited may be retained by the company until the .lose of the season for fincl settlement, and from the aggregate of the amount so retained from each person there shall be, at the end of the scason, before paying the same over to the respective members of the company, deducted all expenses and losses. All expenses of handling, packing and marketiug fruit shall be borne by the several members of the conpany, in proportion to the number of bushcls of fruit with which cach has been credited. All losses and rebates shall be deducted in proportion to the moncy credit of each member.

Artielc 20. Whenever, in the opinion of the Directors it is impossible for the (onipany to receive at its fruit house all the peaches grown by its ncmbers, they may pernit individual memlers to grade and pack the same for shipment through the house, sueh period to be limited by the Dircetors. Reasonable compensation will be ullowed for such grading and packing.

Artiele 21. Permanent or temporary additions, extensions or any new buildings from time to time that may be constructed by the company including the present ice house, the eost of same shall be paid by the stock of issue by a fund suficicnt to mect such costs by an assessment upon the said stock as it shall appear against cach anil every member, and not as an item of general expense. 
Articls 82. The cont of ice and cost of putting same into ice house as it now atands, and each and every season when the waid ice house shall be filled, wall go into the general expense and be pail for as named in Article 10 of the By-lawa.

Article 23. Bofore the annual meeting, as named in Section 3 of the Conotitution, if there slaall be available funds in the treasury after all debts whall have been paid, the Board of Directors then, if in their opinion it shall be dermed best, can order canh dividend to be declared and uaid to each stockholder of record up to the first day
of December of each year.

\section{FORM RECOMME.TILI) FOIR OX'T.IRIO.}

This set of by-laws was prepared by the District Representatives of the Ontario Department of Agrieulture, in consultation with the Nhmuers of Co-Operative Associations. They have been approved by the Department of Agriculture and the Provincial Secretary's Department:-

1. This Association shall bo known as the.......... Marketing Association.

2. The objects of the Association are for the production, grading and selling of to........produets by its members, to purchase supplies, packages, machinery, etc., to buy and sell such other..........products during the season as opportunity presents itself, and to erect, buy, sell, own and control buildings and other materials as
necded in its business. in each year.

3. The annual meeting of the Association shall be held on................

4. Notice of the anuual meeting shall be giren each member in writing by the Secretary not less than one week previous to the date of the meeting.

5. Special meetings may be held at any time upon eall of the President by written notice mailed to each member five days before the meeting. Special meetings shall be called by the President whenever required to do so in writing by any ten members.

6. At any meeting of the Association, ten members shall eonstitute a quorum for the transaetion of business.

7. At the annual meeting a Board of........... Direetors shall be elected, of whom.........shall constitute a quorum at any Board meeting.

8. The offieers whall consist of a President, Viee-President and a Secretary.

9. The officers shall be ehosen by the Direetors from among themselves at the first Board meeting after the annual meeting.

10. At the annual meeting two auditors shall be eleeted.

11. All the elections shall be by ballot, plurality electing, eondueted by two ecrutineers appointed by the Chairman.

12. The Board of Directors shall employ a business Manager, who shall also act as Treasurer of the Association. The business Mannger shall not be a member of the Buarl of Direetors.

13. The President shall preside at all meetings. He shall eall meetings of the Hoard of Direetors and members when necessary, and shall advise with and render snch assistanee to the Januger as may be in his power. In his absence, the ViceI'resident shall hare and exercise all rights and powers of the President.

14. The Secretary shall keep a reeord of the proceedings of all meetings and of all rceeipts and disbursements, s.nd report the condition of the finances annually, or as often as the Directors shall desire.

15. The Iranager shall have eharge of the business in detail, under the direction of the Board of Direetors.

16. The Manager and Treasurer and Seeretary shall give bonds in sueh sums an may be areeptable to the Association.

17. The Directors may select three of their number to act as an Executive Committee (the President to serve as (hairman), to hare general eharge of the affairs of
the Association. 
18. When a racancy shall occur through anj cause in any of the oftiver established by the by-laws of the Association, it shall be filler at the next regular or special meeting.

19. The annual dues of this Association shall be..........payable on or before the date of the annual merting.

20. Each member at the tine of uniting with the Assoriation shall give a pronissory note, payable on demand, to the Association, for the sum of........dolla' 8 , und ful additional........ for each and every........ owned by the member at the me of joining the Association, but in no ense shall the pronissory note be for less a sum than.......... dollars.

21. At the time of uniting with the Association and at the end of each three years after the incorporation of the Association, and not less thun ten days previous to the date of the next annual meeting, each member shall tile witl the Secretary a true statement of the number of.......... ownerl by the member at that time.

22. Within two weeks after the annual meeting at the enl of ench third year the Directors shall require each member to sign a promissory note payable on demand to the Association, of the sum of........dollars, and an additional....... for each an 1 every........ owined by the member at that time, but in no case shall the promissory note be for a less sum than......... dollars. In consideration for the saure the Secretary shall deliver over to the member the note previously given by the membur. duly eancelled and stamped with the seal of the Associntion.

23. The notes of the members shall be the property of the Asecciation and sliall be used by the Directors as collateral security with which to secure nepled capital for the transaction of the business of the Association.

24. Whenever the notes of any of the members are deposited as sceurity for a debt, all the members shall indiridually share the liability in proportion to the ralie of the note giren to the Association by each member.

25. All the surplus moneys in the possession of the Association to be dividen] amongst the nembers shall be proportioned to each member on the basis of the value of thic business done by the member with the Asuociation.

21i. Ang..........producer in..........counts ohall be eligible to become a member by a two-thirds vote of the members at the tims the application is madr.

27. All..........produeed for salc by the members and acceptable to the Manager sliall be delivered to the Association as directed by the Directors, and in prime condition for grading, packing and shipping. Other..........produets may be delivered for sale as determinel by the Directors.

28. The books of the Association shall be audited before the date of the anumal meeting each year. At this mreting a printed stateinent of the receipts and expenditures as audited shall be presented to each member.

29. These by-laws may be amended at any regular or special meeting bj a two. thirds rote of the members present in the affirmative. Totice of such amendments must be givell each member by letter at least five days previous to the meeting.

30. Any nember having a grievance or eause of complaint as to treatment of his................. by the Association, may appeal to the Directora. 


\section{APPENDI \&.}

The following is a list of the cooperative associations oporating in Canade, corrected to dati:-

Prince Edward lsland-

The Co-operative Fruit Co., Charlottetown.

Nova Scotia-

Anburu Eruit Co., Auburn.

Aylesford Fruit Co., Aylesford.

- Benr kiver. Benr River.

Berwick Fruit Co., Berwick.

Blomidon Fruit Co., Blonidou.

Bridgetown Fruit Co., Bridgetown.

"Brookland Fruit Co., Tawreucetown.

Canard Fruit Co., Hillaton.

Central Fruit Co., Clarence.

Clarence liruit Co., Clarener.

Cornwallis Fruit Co., Waterville.

Enterprise Fruit Co., Clarence.

Grand Pré Fruit Co., Grand Pré.

Granville Fruit Co., Upper Grauville.

Kentville Fruit Co., Kentrille.

Fingsport Fruit Co., 'Kingsport.

'Ringston Fruit Co., Kingston.

- Lawrencatowu Fruit Co., I Lawrencetown.

Maple Leaf Fruit Co., Canning.

May Flower Fruit Co., 'Kingsport.

Yiddleton Fruit Co., Middleton.

New Minas Fruit Co., Sunnyside.

Paredise Fruit Co., Paradise.

Plenenat Valley Fruit Co., Berwick.

Port Williams Fruit Co., Port Williams.

Round Hill Yruit Co.. Round Hill.

S. B. Chute Fruit Co., Berwick.

Sheffield Mills Fruit Co., Sheffield Mills.

South Farmington Fruit Co., South Farmington.

Starr Fruit Co., Paradise.

"Union Fruit \& Produce Co., Williamston.

Waterville Fruit Co., Waterville.

\section{Queljec-}

Abbotaford Fruit Growers' Society, Abbotsford.

Horelock Fruit Growers' Co-operative Association, Iravelock.

Socicts Co-opérative Agricole des Fruitiers de Saint Hilaire, St. Hilaire.

Sociête "noperative Agricole de Kamouraska, Ste. Anno-de-la-Pocatiöre.

Société Cornérative de Pomologie de St. Joseph-di-Iac, St. Joseph-du-Lae.

Société Co-optrative Agricole de Rougement, St. Michel de Rongemont.

* All these societies, with the exception of those marked with an asterisk, aro members of the United Fruic Companies Limited, of Nova Scotia, Berwick, N.8. 
Quebec-Concluded.

Sociéti Coopirative Arripole des Produetoun de Fruits do Rouvilles Be Michel de Rougemont.

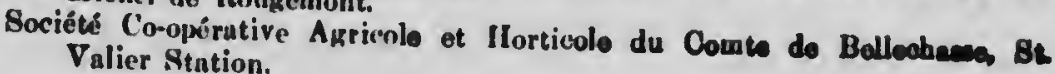
Valier Stution.

Ontario-

Alviuston F. G. A., Aughrim.

Aucuster F. (i. A.. IIau:ilton.

Arkona F. G. A., Arkoma.

Braut F. (i. A., Burfuril.

Brant Paeking F. A., Burford.

Brighton Co-operative F. (i. A., Brighton.

Burgeasville F. G. A., Burgesnville.

Burlingtou F. G. A.. Burliugtou.

Byron F. (1. A., Tamblime C'ormers.

Curador F. (i. A.. Falcoubridge.

Chatham F. A. A., Cliatliain.

Clarkson F. G. A., Clarkson.

Cobourg F. G. A., Baltimoro.

Durham F. G. A., Port Hope.

Foreat F. G. A. Forwarding C.o. Foreat.

Gergetown Co-operntive Associntion, (icorgetown.

Gergian Bay Fruit Growers' Assil., Ltul, Thornbury.

Gleneos F. G. A., Appin.

Gore F. A. A., Norwiel.

Grafton F. G. A., Wieklow.

Grantou F. G. A., Grantou.

Hagersville F. A. A.. IInpersville.

Hatchley Station F. G. A., Hatcliley Station.

Iraldimaud F. (i. A., Duunville

Huron F. G. A., Goderieh.

Ilderton F. G. A., Ilderton.

Inwood F. G. A., Inwood.

Johnson F. G. A., Forest.

Jordon Co-operation Assn., Jordon.

Lambton F. G. A.. Saruia.

Milton F. G. A.. Milton.

Mount Nemo F. G. A., Nelson.

Neweastle F. G. A., Neweastle.

Norfolk F. G. A., Simcoe.

North Brant F. G. A., Cainsville.

Northumberiand Co.-operative F. G. A., Brighton.

Ontarin \& Western Co-operative F. G. A., Grimsby.
Orono F. G. A., Orono.

Oshnwa F. G. A., Oshawa.

Owen Sound F. G. A., Owen Sound.

Oxforl F. F. A., Oxford Centre.

Pelham F. G. A., Fonthill.

Port Burwell F. G. A., Vienna.

Prince Edward F. G. A., Wellington.

Simeoe Fruits Limited, Barrie.

Sparta F. G. A., Sparta.

\footnotetext{
"Nearly all these Ontario associations are members of the Co-operative Fruif
Growers of Ontario, Limiter. Toronto.
} 
Ontario-rinulusled.

At. Catharinew Cold Storare \& Forwardine Oompany, 8t. Catharinea Tilloonburs F. O. A., Tilleonburk.

Wallacebure F. (i. A. Wallaceluire.

Wardaville F. O. A.. Wamlaville.

Watford F. G. A., Wutford.

Welland F. (i. A., Mursliville.

Wentworth F. A. A., IJunilton.

Winoua F. G. A., Winonn.

Hyouing F. A. A., Wyounius.

Britinh Columbia-

('rentoun Fruit I"uinu. C'renton.

Girand Forks F. G. A., Grasid Forks.

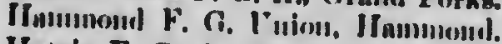

Intxic F. A. A.. Hatzic.

Kelowna Farmers' Exchauge, kelowna.

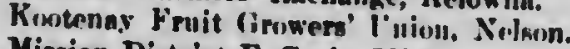

Minaion Distriet F. G. A., Mingion.

Otanagan Fruit Union, Lid., Vernon.

Salmon Arm Farmers' Fxchaune, Salniou Arm.

Vernon Fruit Co., Vernon. 


\section{APEMDE 8.}

The followine ntatiatien have heru conupiled by the Fatcusion of Yarkete Dirislon. 'Tami.k Nu. 1.

Aprisin exported from ('nunda in the yean 1805 to 1911 ineluaire.

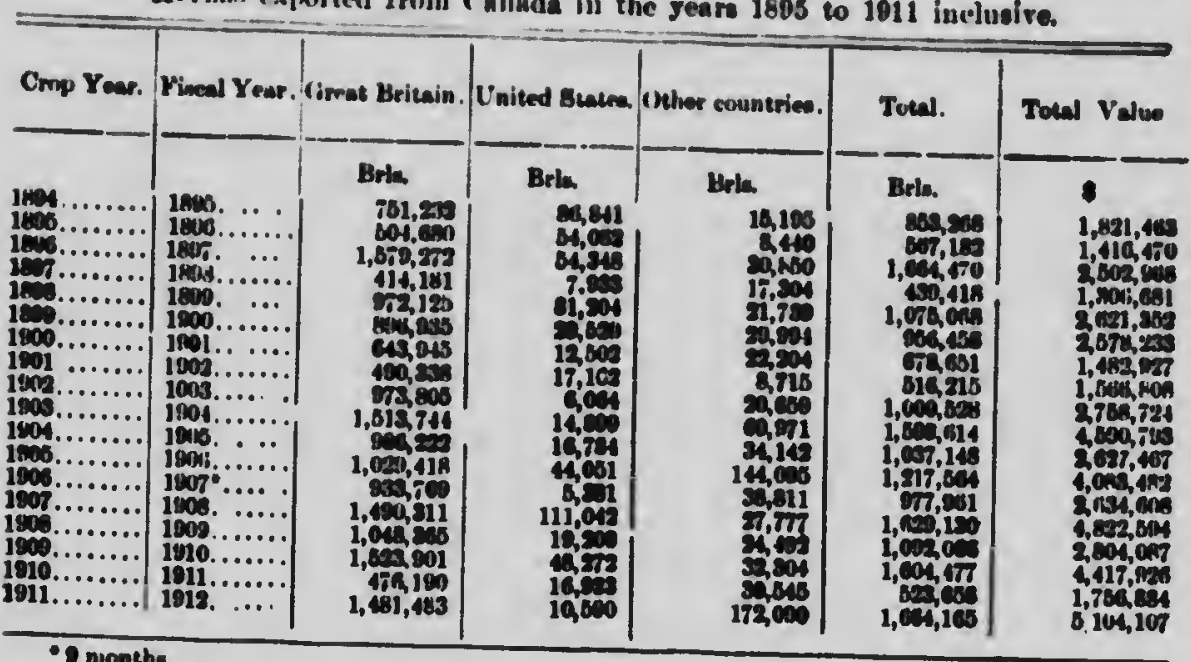

- 1 mionthe.

Nork.-The foregoing statistice relate entirely to the export trade and beretofore we have been in the habit of taking these figures as a criterion for the progress of the he been a In our future calculations, however, we must remember that there

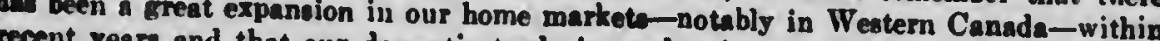
enowing importance.

TAsu: No. 2.

Exports of Canadian Apples by periods for the Years 1006-07 to 1911-12, inclusive.

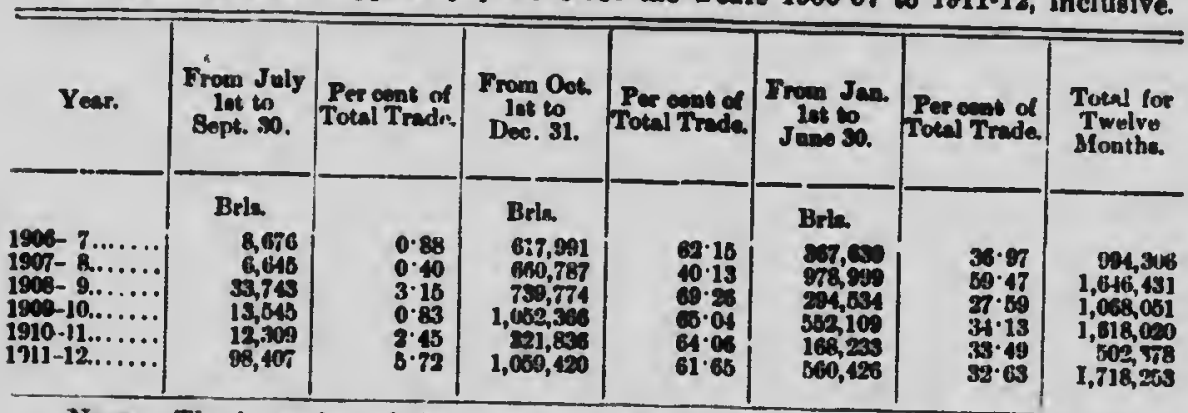

Norz.-The intention of the above tablo is to divide the exports into three periods that will synchronise with the three main divioions of the crop, viz., Early, Fall and Winter apples. Of course the last tro divisions particularly are not clear cut as winter varieties may be shipped before the end of the year and fall rarieties may be carried over into January. The tabulation is interesting, however, in that it show the heavy volume of exports during October, November and December-equal to twotr. rds of the total trade-aud the growth of the export trade in early applea. 
Tamu No. 8.

A resane Yearly Fxports of Apples from Caneda and the Inited Rtated in Fire Year Perinda from 1803 to 1918.

\begin{tabular}{|c|c|c|c|}
\hline \multirow{3}{*}{ Poriod. } & \multicolumn{3}{|c|}{ A renase Yoatly Rrporta. } \\
\hline & Can: & nede. & United Berever \\
\hline & Yran anded Ju & 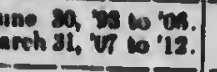 & Years ended Juno 20. \\
\hline 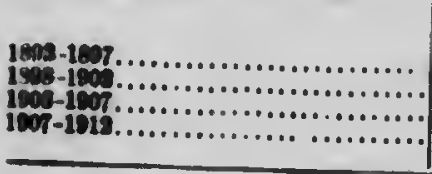 & & $\begin{array}{l}910,19 \\
734162 \\
1,164,04 \\
1,202,000\end{array}$ & 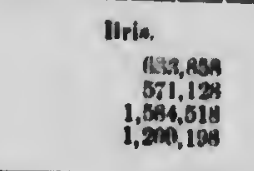 \\
\hline
\end{tabular}

Tamie No. 4.

Showing Quantities of Applew, Bananas and Oranges Imported into the Inited Kingdom in the Years named.

(Year ended Docember 31at).

\begin{tabular}{|c|c|c|c|}
\hline Yeara. & - Appler & Banenan, & Oranges. \\
\hline 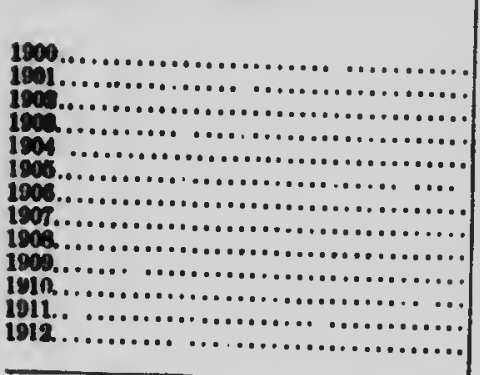 & 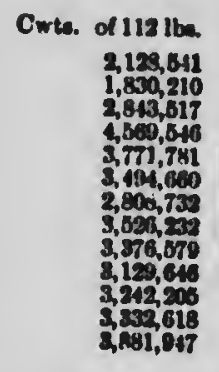 & 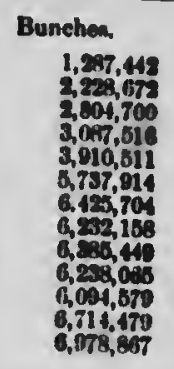 & 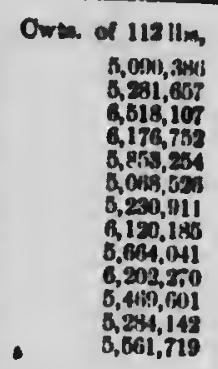 \\
\hline
\end{tabular}

Note.-The importation of bananas and oranges is shown for the reasou that these fruits are the chief competitors of the apple in the inarkets of the Uniter lingdom and exercise an important influeuce on the eonsumptive demand for the and oranges imported sotel thit in the last nine years while the quantity of apples has almoat doubled. 


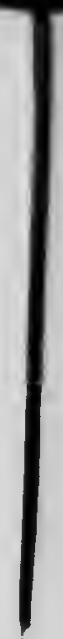





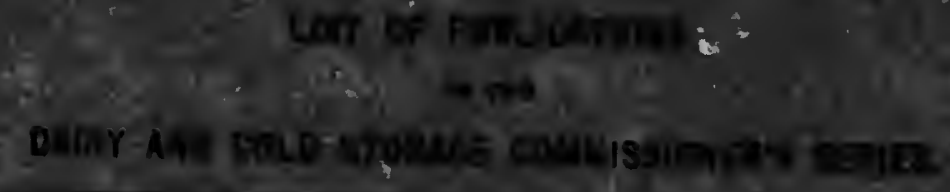

arose

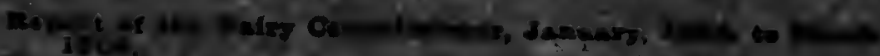

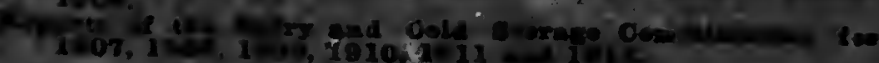
courercum.

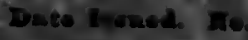

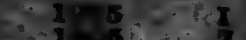

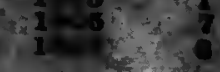
tedo 11

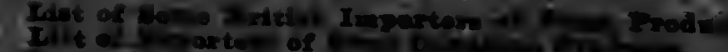

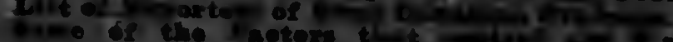

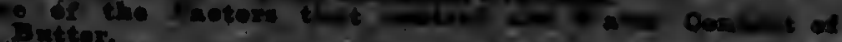

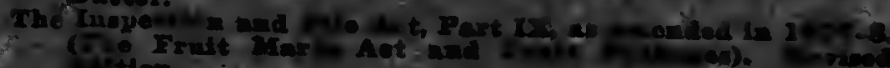

$1000 \%$

$1=i-17$

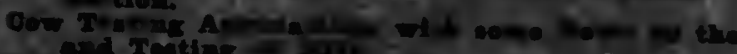

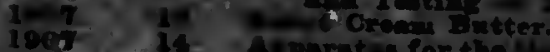

100. 4 is 17

1) $2,7=1$

Alparation fortho

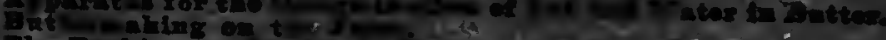

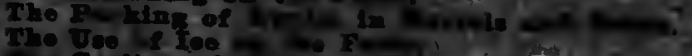

$1,2+28$

110

1010

גis

$1910-32 \mathrm{Ba}$

i il 80

$1011=, 20$

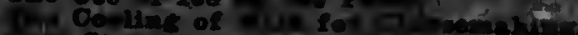

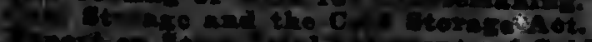

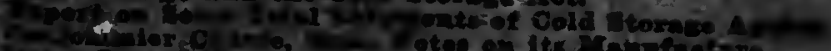

$10113+90$

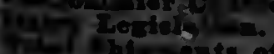

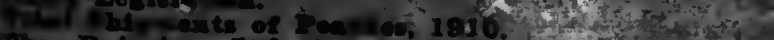

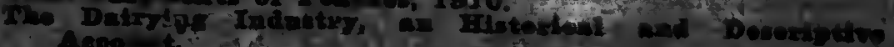

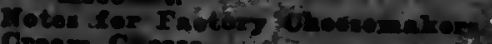

1011. $=20$

I I i t of the of

101112.1

18180.62

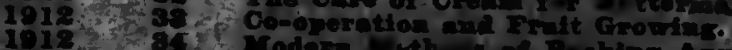

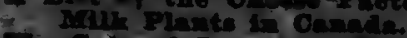

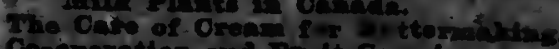

118,03

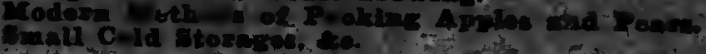

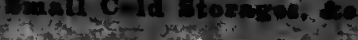

iomoviars.

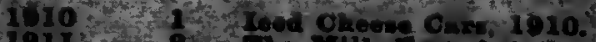

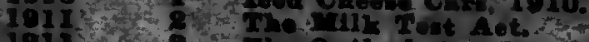

1813

1012

$101 \%$

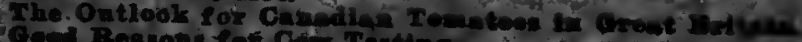

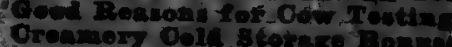

$-1,0$ s

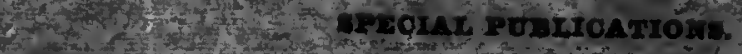

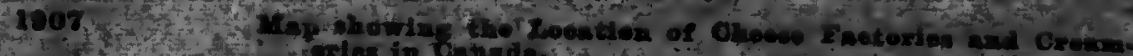

1811

1818

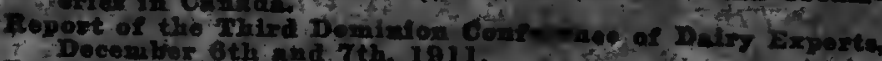

$x+1012$

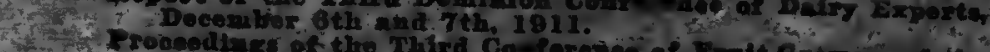

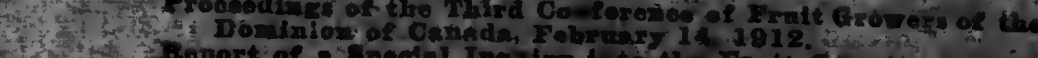

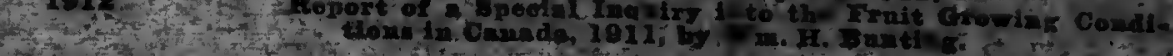

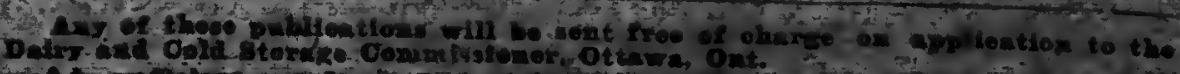

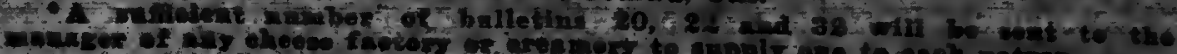

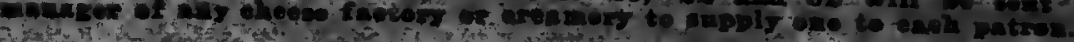




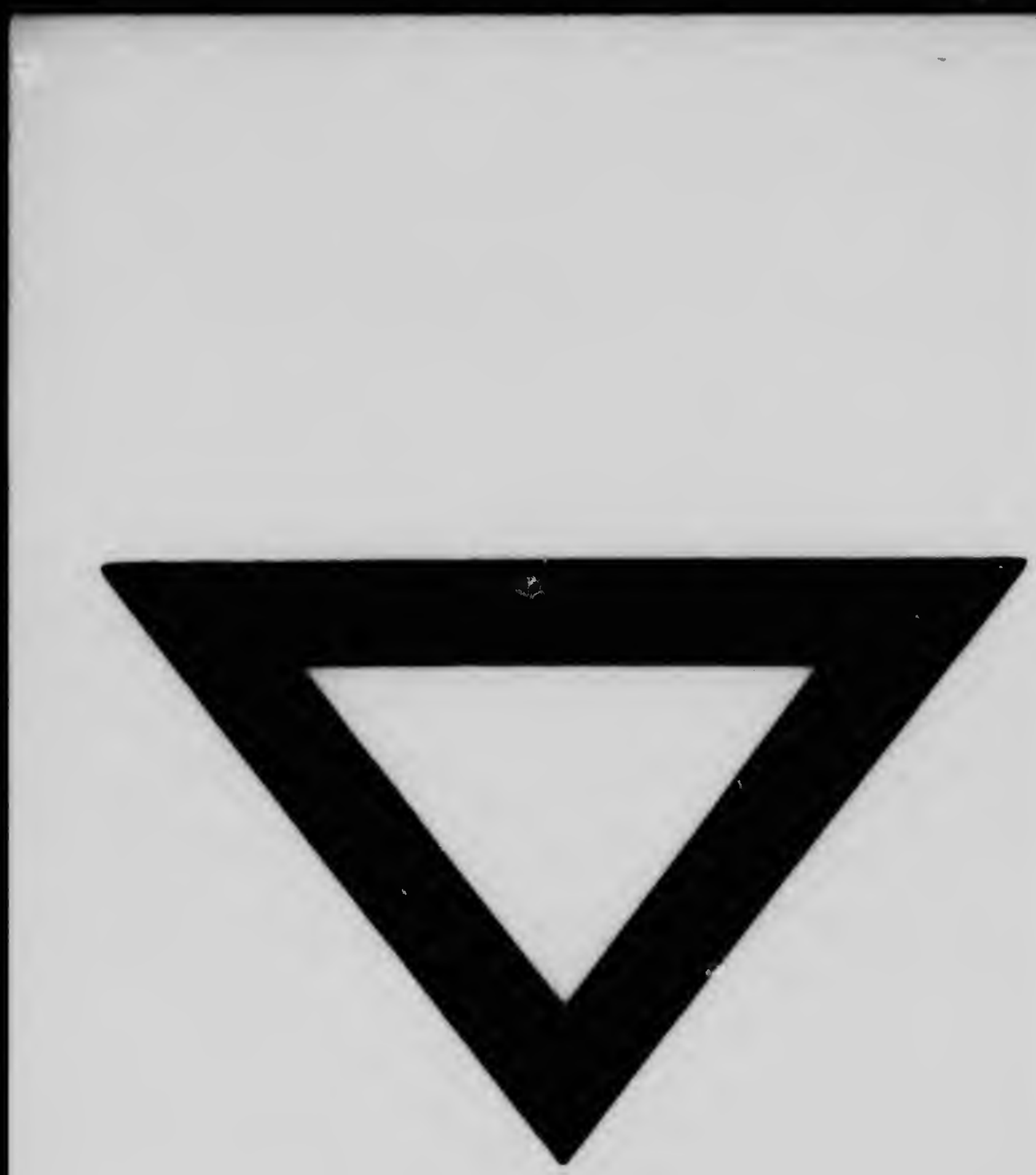

